\title{
Grain size statistics and depositional pattern of the Ecca Group sandstones, Karoo Supergroup in the Eastern Cape Province, South Africa
}

https://doi.org/10.1515/geo-2017-0042

Received August 23, 2017; accepted January 19, 2017

\begin{abstract}
Grain size analysis is a vital sedimentological tool used to unravel the hydrodynamic conditions, mode of transportation and deposition of detrital sediments. In this study, detailed grain-size analysis was carried out on thirty-five sandstone samples from the Ecca Group in the Eastern Cape Province of South Africa. Grain-size statistical parameters, bivariate analysis, linear discriminate functions, Passega diagrams and log-probability curves were used to reveal the depositional processes, sedimentation mechanisms, hydrodynamic energy conditions and to discriminate different depositional environments. The grain-size parameters show that most of the sandstones are very fine to fine grained, moderately well sorted, mostly near-symmetrical and mesokurtic in nature. The abundance of very fine to fine grained sandstones indicate the dominance of low energy environment. The bivariate plots show that the samples are mostly grouped, except for the Prince Albert samples that show scattered trend, which is due to the either mixture of two modes in equal proportion in bimodal sediments or good sorting in unimodal sediments. The linear discriminant function analysis is dominantly indicative of turbidity current deposits under shallow marine environments for samples from the Prince Albert, Collingham and Ripon Formations, while those samples from the Fort Brown Formation are lacustrine or deltaic deposits. The C-M plots indicated that the sediments were deposited mainly by suspension and saltation, and graded suspension. Visher diagrams show that saltation is the major process of transportation, followed by suspension.
\end{abstract}

Keywords: Grain size analysis, hydrodynamic condition, depositional environment, Ecca Group, South Africa

\footnotetext{
*Corresponding Author: Christopher Baiyegunhi: Department of Geology, Faculty of Science and Agriculture, University of Fort Hare, Private Bag X1314, Alice, 5700, Eastern Cape Province, South Africa, E-mail: 201201530@ufh.ac.za; cbaiyegunhi@yahoo.com
}

\section{Introduction}

Grain size is a fundamental feature of siliciclastic sediments and thus, it is one of the important descriptive properties of sedimentary rocks. Grain-size characteristics are widely used by geologists to reveal depositional process, hydrodynamic condition and depositional environment [1]. As applied in a variety of sediments deposited in various environments, grain size analysis plays an important role in understanding and defining the hydrodynamic mechanisms and depositional environments of detrital sediments. [2] documented that grain-size analysis is an important tool used to texturally characterise sediment properties, classify sedimentary rocks and define depositional environments. In addition, grain size parameters also provide valuable clues to the sediment provenance, transportation mechanism and depositional conditions [3]. Several researchers including [1, 3-24] have shown that indeed each sedimentary environment supposedly exhibits distinctively different grain-size characteristics that distinguish them from sediments deposited in different environments. Furthermore, these studies documented that as soon as sediments from recent environments have been 'fingerprinted' by grain size properties, the information can be deduced and used in interpretation of the sediment depositional history. However, [1, 25, 26] highlighted the ambiguity of grain-size analysis in respect of depositional environments.

According to [25], there are three main aspects of particle size that sedimentologists focus on: (a) the method for measuring grain size and representing it in terms of grade scale, (b) techniques for quantifying grain size data and presenting them in a statistical or graphical form and (c) the genetic significance of the data. Graphical and mathematical methods are the two main ways for represent-

\footnotetext{
Kuiwu Liu, Oswald Gwavava: Department of Geology, Faculty of Science and Agriculture, University of Fort Hare, Private Bag X1314, Alice, 5700, Eastern Cape Province, South Africa
} 
ing grain-size data. The former often involves plotting the grain-size data on bivariate diagrams in which either the cumulative weight percent or individual weight percent is plotted against the sieve size in phi units. The latter entails the use of mathematical expression or statistical parameters to represent grain-size data. Grain size analysis produces statistical parameters like calculated mean (verbal grain size), standard deviation (verbal sorting), mode, kurtosis and skewness. Two component variation diagrams and log-probability plots are the two main types of graphical plots that have been widely used in environmental studies when it comes to grain size analysis.

$[11,27]$ supported the use of the two component variation diagrams in which one statistical parameter is plotted against another (i.e. mean grain-size versus standard deviation and kurtosis versus skewness). This method allows separation various environments like river and beach from each other based on numerical parameters. On the other hand, several researchers have recommended the use of log-probablility plots because of the environmental significance that is associated with the shapes of grain-size cumulative curves [10, 28]. [10] documented that such curves usually show two or three straight-line segments instead of the single straight line anticipated for a normally distributed population. These curve segments are interpreted by $[10,28]$ to represent subpopulations of grains transported concurrently by different mechanism of transportation such as traction, saltation and suspension. The differences in shapes of the curve as well as the position of truncation points of the curve segments putatively allow discrimination of sediments from different environments. However, a number of researchers have reported success in using the two methods, while others have failed to identify the correct environment [19-23].

The Permian Ecca Group, Karoo Supergroup is a sedimentary sequence that accumulated between the Late Carboniferous Dwyka Group and the Late Permian-Middle Triassic Beaufort Group [29]. The stratigraphic sequence of the Ecca Group in the Eastern Cape Province consists of dark grey shale, sandstones and mudrocks with subordinate chert and yellow claystones (tuff). So far, the Ecca Group in the area received a very casual attention for its sedimentological details, in spite of the excellent preservation of the stratigraphic sequence, sedimentary structures, and variation in lithological characteristics (i.e. grain sizes and texture). Recently, the use of more sophisticated multivariate statistical methods like factor analysis and discriminant functions have yielded more successful results in identifying the correct depositional process and environments and this is supported by the works of [21-23, 3032]. This study provides the first relatively detailed grain- size analysis of sandstones from part of the Ecca Group in the study area. The results presented in this paper are based on the generation and integration of basic data on grain size parameters and multivariate statistical measures. Based on various basic statistical data, the bivariate plots between different parameters, linear discriminant function, Passega diagram and log-probability curves, an attempt has been made to interprete the probable depositional environments and depositional process of the sediments in the area.

\section{General geology and stratigraphy}

The word "Karoo" was derived from the Main Karoo Basin of South Africa to describe sedimentary fill of all basins of akin age across Gondwana [23, 29]. The Main Karoo Basin of South Africa is bordered in the southern part by a fold belt (Cape Fold Belt), while the northern part is held by Archean Kaapvaal Craton [33]. It is a unique type of basin of all the Karoo basins in southern Africa since it contains the thickest and stratigraphically most complete mega-sequence of several depositories of the PermoCarboniferous to Jurassic age sediments in southwestern Gondwana continent [33]. In addition, it serves as a datum for classifying Karoo basins in central and southern Africa. The bulk of the Karoo strata occurs in the Main Karoo Basin, with maximum preserved thickness adjacent to the Cape Fold Belt in excess of $6 \mathrm{~km}$ [34]. The basin covers up to 700, $000 \mathrm{~km}^{2}$ and represents about $100 \mathrm{Ma}$ of sedimentation spanning from $280 \mathrm{Ma}$ to $180 \mathrm{Ma}$, and has its rocks covering almost half of the area of South Africa [35]. The sedimentary succession reflects changing environments from glacial to marine, deltaic, fluvial and finally aeolian [36].

Generally, the Karoo Supergroup is subdivided into five main groups, namely; the Dwyka (Late Carboniferous), Ecca (Early Permian), Beaufort (Late PermianMiddle Triassic), Stormberg (Late Triassic-Early Jurassic) and Drakensberg Groups (Middle Jurassic) [37]. The Drakensberg lavas are believed to have terminated sedimentation in the basin in the Middle Jurassic [36]. Rubidge in [29] devised the term "Ecca" for argillaceous sedimentary strata exposed in the Ecca Pass, near Grahamstown in the Eastern Cape Province, South Africa. Stratigraphically, the Ecca Group in the study area can be subdivided into five formations, namely, the Prince Albert, Whitehill, Collingham, Ripon, and Fort Brown Formations [38-40]. These formations constitute the southern Ecca stratigraphy and they are partially correlative to the Pietermar- 
itzburg, Vryheid and Volkrust Formations in the northeast part of the Main Karoo Basin [33] (Figures 1 and 2). It is estimated that the group attained a thickness of about $3000 \mathrm{~m}$ in the southern part of the basin, while it is considerably thinner elsewhere in the northern part of the basin [41].

Tectonism and climate are the two main allogenic controls that influenced the sedimentary fill of the Karoo basin $[29,33,35,42,52]$. During the Karoo time, the tectonic regimes changed from mainly flexural in the south, in response to processes of subduction, accretion and mountain building along the Panthalassan (palaeo-Pacific) margin of Gondwana, to extensional in the north, in response to processes of spreading along the Tethyan margin of Gondwana. In addition, [29] documented that the tensional episodes initiated during the Karoo time led to the development of the early Tethyan spreading centre, which continued to control deposition in the Karoo until the Middle Jurassic when Gondwana break-up. Propagation of tensional stresses from the Tethyan margin to the south started during the Late Carboniferous, thus controlling the rate of deposition of Karoo sediments in the developed grabens and rift structures. The depositional environments of the Karoo succession varies from glacial and partly marine in the Dwyka Group, to marine in the Ecca Group, then to fluvial and aeolian in the overlying Beaufort and Stormberg Groups respectively [33]. During the deposition of the Dwyka and Ecca Groups, an interior seaway transgressed the Karoo Basin, but it totally regressed from the confines of the preserved basin at the end of Ecca time [42]. The inter-relationship between the base level changes and supply of sediment controls the extent in which the available accommodation was used up by sedimentation [43]. This relationship defines the underfilled, filled and overfilled depositional stages in the evolution of Karoo foreland basin that is dominated by deep marine (Dwyka-lower Ecca), shallow marine (upper Ecca) and fluvial sedimentation (Beaufort-Stormberg) respectively [33]. It is most likely that the Prince Albert and Whitehill Formations were formed in a reducing deep water marine environment, whilst the Collingham Formation is a deep water turbidite deposit. The Ripon Formation was formed in a shallow marine to deltaic environment whereas the overlying Fort Brown Formation was developed in a broad continental margin of lacustrine environment. More details on the geology, stratigraphy and tectonic setting of the Karoo Basin can be found in $[29,33,35,42,44-53]$.

\section{Materials and methods}

Thirty-five (35) representative thin sections of different types of sandstone from the Ecca Group were selected systematically to cover textural variations (physical character such as grain size, shape and arrangement) were considered. The samples were analysed for their grain-size parameters and statistical relationships. Grain-size measurements were conducted on the thin sections under petrographic microscope using an ocular with a millimetre scale. At least 500 grains per thin section were measured for each sample using the conventional method of grain's longest axis measurement [54-56]. The frequency of grainsize ranges were calculated and the grain-size classes were determined using the Udden-Wentworth grade scale [57, 58]. The dimension of grain-sizes (millimetres) were converted to a phi scale which is a logarithmic scale to base 2 .

$$
\varnothing=-\log _{2} D
$$

where $\varnothing$ is the phi size and $D$ is the grain diameter in millimetres.

The results of the grain-size analysis were graphically represented in the form of cumulative curves. On the other hand, the average grain size and sorting of the samples cannot be actually determined, thus mathematical techniques which allow statistical treatment of grain-size data was derived from the cumulative curves (Figure 3) to describe grain-size distribution mathematically.

The statistical parameters of grain-size distribution were calculated using equation proposed by [4] (Table 1). Bivariate scatter plots were employed to discriminate between depositional settings based on the textural variations of sediment. The Sahu's $[7,59]$ linear discriminant function (LDF) was used to determine and distinguish processes and environments of deposition. In addition, grain size statistical parameters, C-M plots and log-probability curves were used to reveal the different depositional processes, mechanism of sedimentation and energy condition of the transporting medium $[6,10]$.

The parameters employed to describe the grain size distribution are categorised into four main groups that include, the mean, standard deviation, skewness, and kurtosis. The formula for calculating graphic mean, standard deviation, skewness and kurtosis is depicted in Table 1. The parameters are defined by [1] as follows:

- Mean grain size $\left(M_{Z}\right)$ is a descriptive parameter of grain-size that measures the arithmetic average size of all the particles in a sample. It indicates the central tendency of a grain size distribution. An approximation of the arithmetic mean was determined by picking 


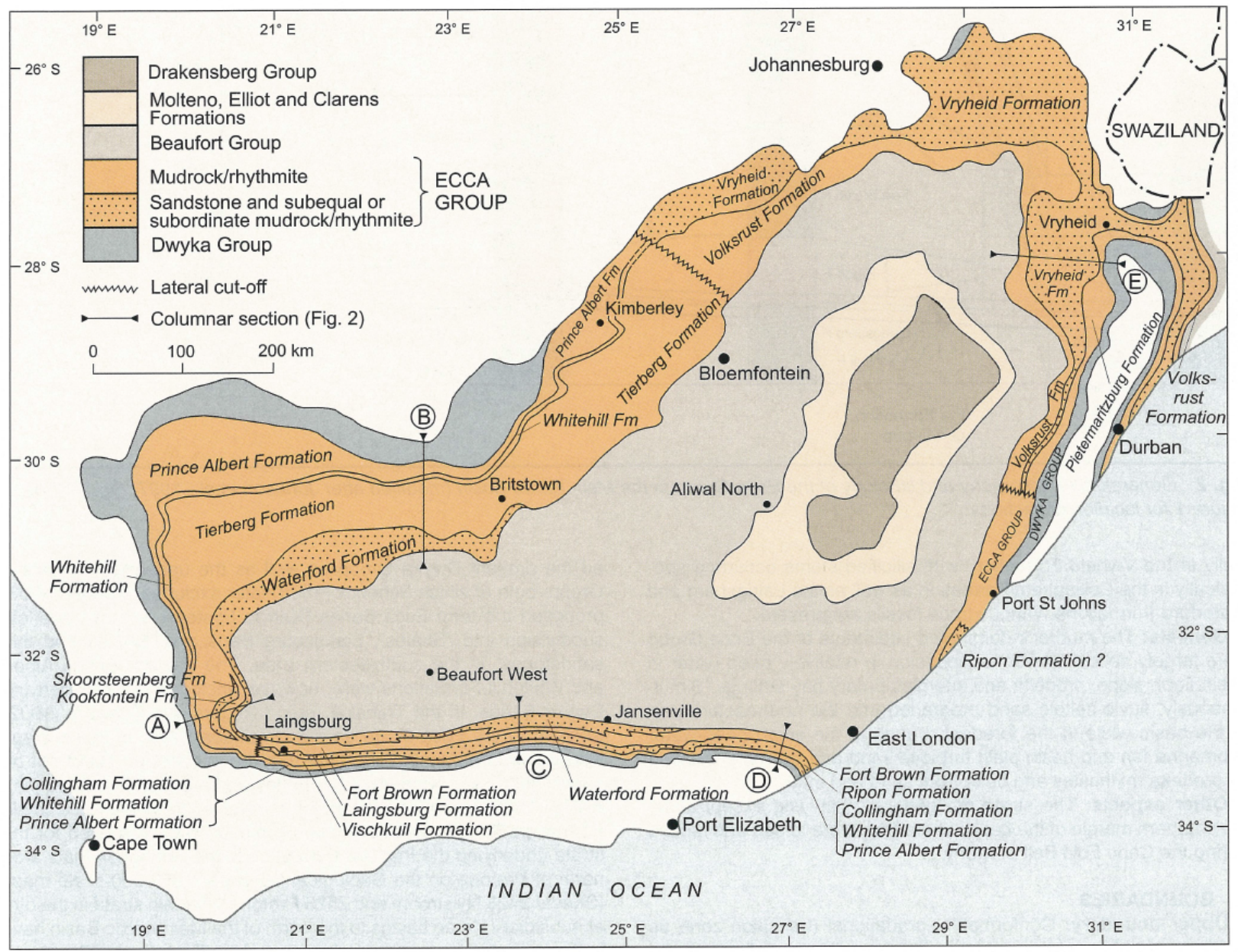

Figure 1: Distribution of the Ecca Group and its constituent formations [50].

Table 1: Formulas for calculating grain-size statistical parameters by graphical methods (after [4]).

\begin{tabular}{lc}
\hline Graphic mean $\left(M_{Z}\right)$ & $M_{Z}=\frac{\varnothing_{16}+\varnothing_{50}+\varnothing_{84}}{3}$ \\
\hline Inclusive graphic standard deviation $\left(\sigma_{i}\right)$ & $\sigma_{i}=\frac{\varnothing_{84}-\varnothing_{16}}{4}+\frac{\varnothing_{95}-\varnothing_{5}}{6.6}$ \\
\hline Inclusive graphic skewness $\left(S K_{i}\right)$ & $S K_{i}=\frac{\left(\varnothing_{84}+\varnothing_{16}-2 \varnothing_{50}\right)}{2\left(\varnothing_{84}-\varnothing_{16}\right)}+\frac{\left(\varnothing_{95}+\varnothing_{5}-2 \varnothing_{50}\right)}{2\left(\varnothing_{95}+\varnothing_{5}\right)}$ \\
\hline Graphic kurtosis $\left(K_{G}\right)$ & $K_{G}=\frac{\left(\varnothing_{95}-\varnothing_{5}\right)}{2.44\left(\varnothing_{75}-\varnothing_{25}\right)}$
\end{tabular}

Where $\varnothing_{5}, \varnothing_{16}, \varnothing_{25}, \varnothing_{50}, \varnothing_{75}, \varnothing_{84}$ and $\varnothing_{95}$ represents $5^{\text {th }}, 16^{\text {th }}, 25^{\text {th }}, 50^{\text {th }}, 75^{\text {th }}, 84^{\text {th }}$ and $95^{\text {th }}$ percentile, respectively, on the cumulative curve. 


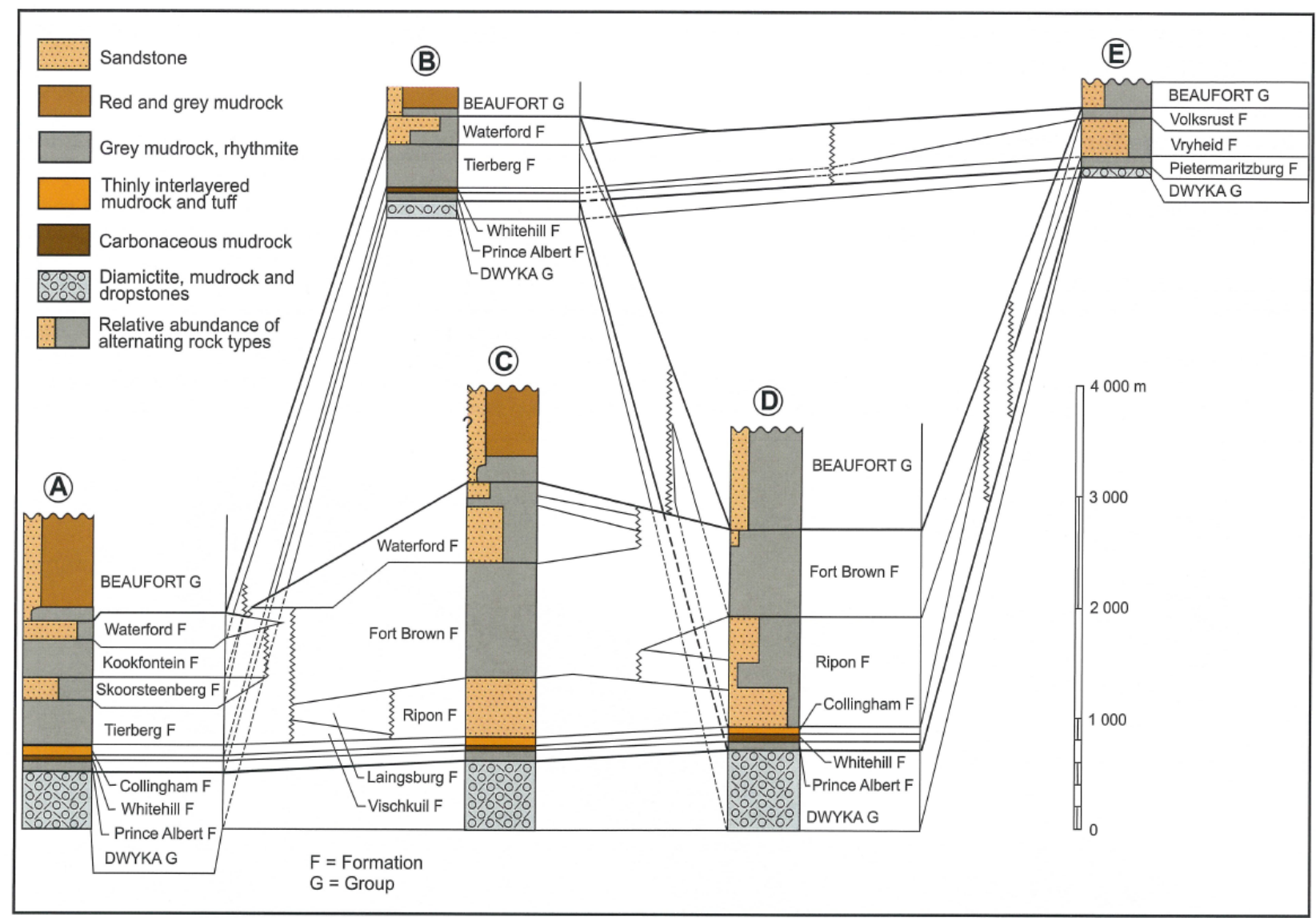

Figure 2: Generalized stratigraphy and lithology of the Ecca Group in the Main Karoo Basin [50].


Figure 3: Illustration of histogram (left) and cumulative curve (right) plotted for one of the Collingham Formation sample. In addition, the cumulative curve shows the method for calculating percentile values. selected percentile values from the cumulative curve and averaging those values using the graphic mean formulae depicted in Table 1.

- Standard deviation or grain-size sorting is a measure of a range of grain sizes present and the degree of spread or scatter of these sizes around the average or mean size. The inclusive graphic standard deviation is the mathematically expression for sorting $\left(\sigma_{i}\right)$. The verbal term for sorting that correspond to the values of the inclusive graphic phi standard deviation is depicted in Table 2 (After [9]). 
Table 2: The verbal terms for sorting that correspond to the values of the inclusive graphic standard deviation (After [9]).

\begin{tabular}{ll}
\hline \multicolumn{1}{c}{ Phi standard deviation } & \multicolumn{1}{c}{ Verbal sorting } \\
\hline$<0.35 \varnothing$ & Well sorted \\
0.35 to $0.50 \varnothing$ & Moderately well sorted \\
0.50 to $0.70 \varnothing$ & Moderately sorted \\
0.70 to $1.00 \varnothing$ & Poorly sorted \\
1.00 to $2.00 \varnothing$ & Very poorly sorted \\
2.00 to $4.00 \varnothing$ & Extremely poorly sorted \\
$>4.00 \varnothing$ & \\
\hline
\end{tabular}

- Skewness is a measurement of the degree of symmetry of grain-size distribution or it reflects sorting in the tails of the distribution. Also, it is a descriptive parameter that determines the majority of the grain-size measurement inclusive graphic skewness. The more the calculated skewness values deviate from zero, the more the skewness.

- Kurtosisis a measure of the sharpness or peakedness of the grain-size frequency curve. It is calculated by comparing the spread or the sorting of the tails in the central part of the distribution to the spread in the tails.

\section{Results and discussion}

\subsection{Grain-size statistics}

The cumulative volume percentage frequency curves show that most of the Permian Ecca sandstones are unimodal in nature with peaks at $2.5 \varnothing, 3.0 \varnothing$, and $3.5 \varnothing$ (Figures 4, 5 and 6) and mostly display near asymmetrical distribution. Four samples from the Prince Albert Formation (PA2-5) are bimodal in nature with peaks at 2.5 $\varnothing$ and $4.0 \varnothing$ (Figure 4). However, one of the sample is positively (fine) skewed (PA3), while others show near asymmetrical distribution. This bimodality is probably due to low energy of the marine setting. The unimodality of some of the Ecca sandstones indicate the consistent depositional process during which the sediments were settled. The positively skewed distribution in the Prince Albert sediment shows that the finer fraction is abundant in the depositional environment (Figure 4).

Most of the graphic curves for the samples of the Collingham, Ripon and Fort Brown Formations (Figures 5, 6 and 7) display almost similar trends, showing moderate well sorting to well sorting. The grain-size diameters range from -0.5 to $4.5 \varnothing$ classes on the Udden-

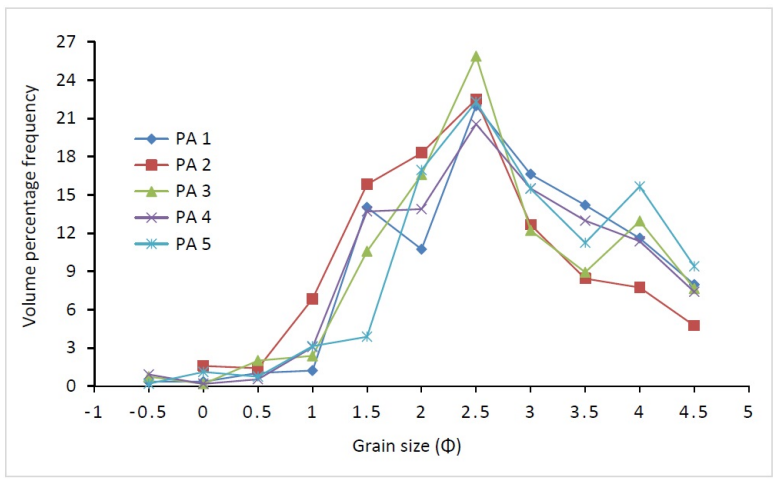

Figure 4: Volume percentage curves of samples from the Prince Albert Formation.

Wentworth grade scale. Most of the sandstones from the Collingham Formation are very fine grained $(3-4 \varnothing)$, while sandstones from other formations are mostly fine grained $(2-3 \varnothing)$. The presence and dominance of very fine-fine grained populations in the area, could be attributed to deposition of sediments mainly by low energy marine currents based on the grain size descriptive statistics. The bimodal nature as well as the absence of a particular trend in the Collingham Formation sandstones are probably due to mixing of particles supplied or brought in by different processes or tranporting agents. Alternatively, it could also be due to the mineral composition differences.

\subsection{Grain-size parameters}

A series of grain-size statistical parameters (i.e. mean, standard deviation, skewness and kurtosis) were calculated from the grain-size distribution curves (After [4]). The parameters used to represent grain-size characteristics of the Permian Ecca sandstones (Table 5) are as follows: 
Table 3: Verbal terms for skewness corresponding to the calculated skewness (After [9]).

\begin{tabular}{ll}
\hline \multicolumn{1}{c}{ Calculated skewness } & \multicolumn{1}{c}{ Verbal skewness } \\
\hline$>+0.30$ & Strongly fine skewed \\
+0.30 to 0.10 & Fine skewed \\
+0.10 to -0.10 & Near symmetrical \\
-0.10 to -0.30 & Coarse skewed \\
$<-0.30$ & Strongly coarse skewed \\
\hline
\end{tabular}

Table 4: Verbal terms for kurtosis that correspond to the calculated kurtosis (After [9]).

\begin{tabular}{|c|c|}
\hline Calculated kurtosis & Verbal kurtosis \\
\hline$<0.67$ & Very platykurtic \\
\hline 0.67 to 0.90 & Platykurtic \\
\hline 0.90 to 1.11 & Mesokurtic \\
\hline 1.11 to 1.50 & Leptokurtic \\
\hline 1.50 to 3.00 & Very leptokurtic \\
\hline$>3.00$ & Extremely leptokurtic \\
\hline
\end{tabular}

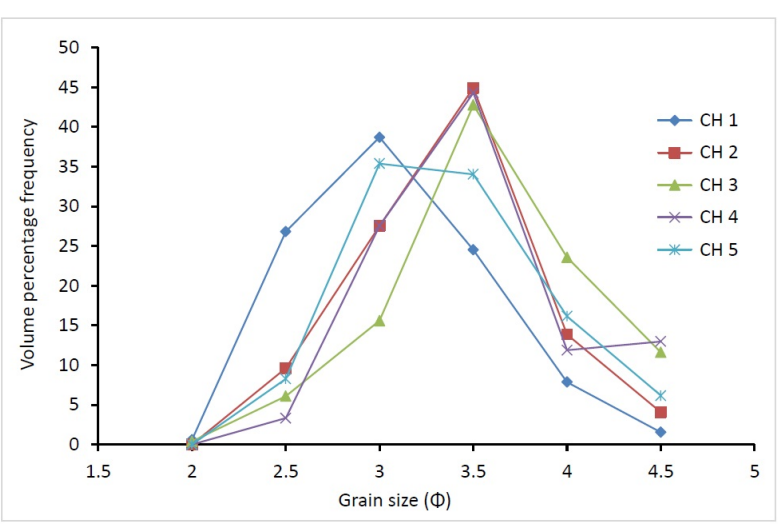

Figure 5: Volume percentage curves of samples from the Collingham Formation.

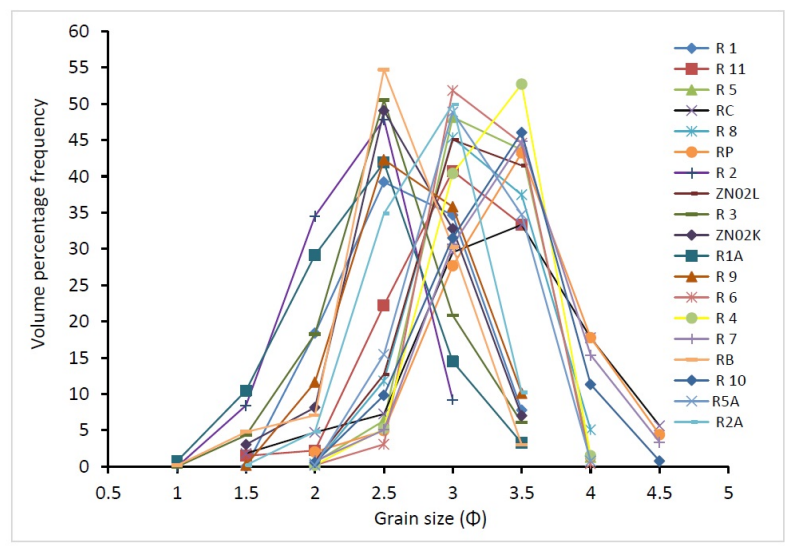

Figure 6: Volume percentage curves of samples from the Ripon Formation.

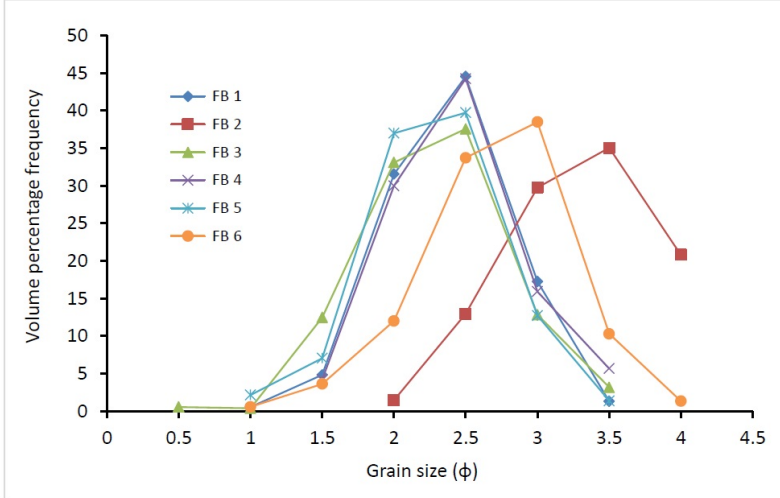

Figure 7: Volume percentage curves of samples from the Ripon Formation.

\subsubsection{Graphic mean $(\mathrm{Mz})$}

The graphic mean size is a parameter that relates to the overall grain-size. It is the average size of the sediment represented by $\varnothing$ mean size and connotes the index of energy conditions [6]. The calculated mean values range from $2.03 \varnothing$ to $3.34 \varnothing$ with average values of $2.49 \varnothing, 3.13 \varnothing$, $2.71 \varnothing$ and $2.32 \varnothing$ for the Prince Albert, Collingham, Ripon and Fort Brown sediments respectively (Figure 8 and Table 6). The average mean grain-size values of the Permian Ecca sediments in the area point to the predominance of fine sand (averaging 2.68 $\varnothing$ ). Likewise, it may show local variations within the formations, ranging from fine to very fine sands. The general variation in the mean size points to fluctuations in the energy condition during sediment deposition. Furthemore, the predominance of fine grained 
sediments and absence of coarse-grained sediments indicate a moderately low energy conditions of deposition [1].

\subsubsection{Inclusive graphic standard deviations ( $\sigma$ 1)}

The inclusive standard deviation measures the sorting or uniformity of the grain-size distribution. It also indicate the fluctuations in the hydrodynamic energy conditions of depositional environment [7]. The inclusive graphic standard deviation values range from $0.32 \varnothing$ to $1.03 \varnothing$ and these values indicate that the Ecca sediments in the area are mainly well-sorted with some being poorly sorted in nature (Figure 8 and Table 6). The values range between 1.02-1.03 $\varnothing$ (poorly sorted), 0.50-0.56 $\varnothing$ (moderately well sorted), 0.32-0.63 $\varnothing$ (well sorted tomoderately well sorted) and $0.44-0.53 \varnothing$ (well sorted to moderately well sorted) for the Prince Albert, Collingham, Ripon and Fort Brown sediments respectively. Generally, the moderately well sorted nature of the sediment could be due to partial winnowing action as well as the addition or influx of previously sorted sediments in marine environment $[17,60,61]$.

\subsubsection{Inclusive graphic skewness (Sk 1)}

The graphic skewness is a measure of grain-size distribution that reflects the grain spread characteristics in the tails of the distribution. An asymmetrical curve with excess fine particles has a fine-size tail and displays a positive phi $(\varnothing)$ value, while one with excess coarse material shows negative phi $(\varnothing)$ value. A zero phi $(\varnothing)$ value is indicated by a symmetrical curve. The values of inclusive graphic skewness ranges from -0.09 to $0.16 \varnothing$ (near symmetrical to fine skewed), with an average of $0.01 \varnothing$ (near symmetrical). Most of the samples fall in the nearsymmetric field (Table 6). Only one sample (PA 3) from the Prince Albert Formation falls in the fine skewed field. [15] documented that the near symmetrical nature of sediments perhaps indicate the absence of extreme conditions like tidal variations, wave breaking and seasonal supply of detrital materials.

\subsubsection{Graphic kurtosis (K G )}

The graphic kurtosis reflects the sharpness or peakedness of the grain-size distribution. Sharp peaked curves point to better sorting in the central portion of the grain-size distribution than in the tails, while the flat-peaked curves shows otherwise $[1,8]$. The graphic kurtosis values for the Ecca sediments range from 0.76 to $1.21 \varnothing$, which falls in the platykurtic to leptokurtic field (Figure 8). The average graphic kurtosis values of the Permian Ecca sediments in the area indicate the predominance of mesokurtic field (averaging $0.99 \varnothing$ ). These values range from 0.85 $1.01 \varnothing$ (platykurtic to mesokurtic), 0.96-1.20 $\varnothing$ (mesokurtic to leptokurtic), 0.76-1.21 $\varnothing$ (platykurtic to leptokurtic) and 0.94-1.05 $\varnothing$ (mesokurtic) for the Prince Albert, Collingham, Ripon and Fort Brown sediments respectively. The variations in kurtosis values are due to changes in the flow characteristics of the depositional medium [62]. The dominance of fine sand-size particles of platykurtic-mesokurtic nature and roundness of the particles reveal maturity of the sands. This could be attributed to the accumulation of fine sand-size particles in a dominant low-energy marine environment [61]. The well-sorted sediments with low kurtosis values in the Fort Brown Formation possibly implies that part of the sediments achieved their sorting in a relatively high energy environment.

\subsection{Bivariate plots of statistical parameters}

The combination of several textural parameters in the form of bivariant plots have been used to identify depositional environment [63]. The bivariate plots are based on the assumption that statistical parameters reliably reflect differences in the fluid-flow mechanisms of sediment transportation and deposition [30]. Several researchers like $[19,21,30-32,64]$ have proven and documented that bivariate plots serve as reliable tools for identifying mechanisms of different environments of sedimentation. Furthermore, they reported that the bivariate plots are the most important and frequently used plots $[4,63,65,66]$ These plots have also been attempted to differentiate between marine and fluvial sands. The bivariate plot of skewness against standard deviation, skewness versus mean, kurtosis against skewness, and standard deviation versus mean were used to distinguish between the different depositional settings.

\subsubsection{Graphic standard deviation (sorting) versus mean size}

The bivariate plot of graphic standard deviation (sorting) against mean shows that the Ecca samples are poorly to well sorted and are very fine to fine sand (Figure 9a). Sediments that are well sorted out during longer transportation have relatively the same grain sizes and if there are different sizes the sediment were probably deposited close to 
Table 5: Graphic measures and grain-size parameters of the samples from the Ecca Group.

\begin{tabular}{|c|c|c|c|c|c|c|c|c|c|c|}
\hline SAMPLE & $\varnothing 1$ & $\varnothing 5$ & $\varnothing 16$ & $\begin{array}{c}\varnothing \\
25\end{array}$ & $\varnothing 50$ & $\varnothing 75$ & $\varnothing 84$ & $\varnothing 95$ & $C(\mu \mathrm{m})$ & $\mathbf{M}(\mu \mathrm{m})$ \\
\hline FB6 & 1.03 & 1.53 & 1.99 & 2.13 & 2.5 & 2.83 & 2.95 & 3.32 & 490 & 177 \\
\hline FB5 & 0.90 & 1.21 & 1.59 & 1.72 & 2.05 & 2.36 & 2.48 & 2.86 & 523 & 245 \\
\hline FB4 & 1.40 & 1.51 & 1.7 & 1.85 & 2.18 & 2.47 & 2.68 & 3.06 & 380 & 220 \\
\hline FB3 & 1.00 & 1.16 & 1.54 & 1.68 & 2.05 & 2.38 & 2.5 & 2.93 & 500 & 245 \\
\hline FB2 & 1.90 & 2.14 & 2.53 & 2.68 & 3.08 & 3.44 & 3.61 & 3.88 & 268 & 116 \\
\hline FB1 & 1.04 & 1.46 & 1.67 & 1.81 & 2.14 & 2.43 & 2.57 & 2.9 & 485 & 230 \\
\hline R 10 & 2.02 & 2.23 & 2.58 & 2.74 & 3.09 & 3.36 & 3.46 & 3.81 & 247 & 117 \\
\hline RB & 1.10 & 1.50 & 2.04 & 2.12 & 2.35 & 2.64 & 2.79 & 2.97 & 470 & 198 \\
\hline R5A & 2.02 & 2.16 & 2.51 & 2.60 & 2.86 & 3.15 & 3.30 & 3.44 & 246 & 140 \\
\hline $\mathrm{R} 7$ & 2.00 & 2.42 & 2.67 & 2.82 & 3.15 & 3.43 & 3.59 & 3.945 & 250 & 110 \\
\hline R 4 & 2.10 & 2.46 & 2.63 & 2.74 & 3.04 & 3.28 & 3.37 & 3.47 & 238 & 123 \\
\hline R 6 & 2.10 & 2.52 & 2.62 & 2.71 & 2.95 & 3.22 & 3.34 & 3.46 & 235 & 131 \\
\hline $\mathrm{R} 2 \mathrm{~A}$ & 1.58 & 2.00 & 2.16 & 2.29 & 2.6 & 2.85 & 2.94 & 3.25 & 343 & 165 \\
\hline R 9 & 1.54 & 1.71 & 2.05 & 2.16 & 2.45 & 2.79 & 2.92 & 3.25 & 347 & 187 \\
\hline R1A & 1.00 & 1.20 & 1.58 & 1.74 & 2.12 & 2.41 & 2.56 & 2.94 & 500 & 230 \\
\hline ZN02K & 1.35 & 1.62 & 2.05 & 2.14 & 2.40 & 2.73 & 2.86 & 3.14 & 400 & 187 \\
\hline R 3 & 1.10 & 1.52 & 1.79 & 2.02 & 2.27 & 2.55 & 2.76 & 3.08 & 470 & 208 \\
\hline ZN02L & 2.01 & 2.17 & 2.53 & 2.63 & 2.91 & 3.20 & 3.32 & 3.44 & 249 & 136 \\
\hline R 2 & 1.04 & 1.29 & 1.61 & 1.74 & 2.07 & 2.33 & 2.43 & 2.73 & 485 & 240 \\
\hline $\mathrm{RP}$ & 1.90 & 2.30 & 2.66 & 2.83 & 3.18 & 3.47 & 3.67 & 3.98 & 268 & 110 \\
\hline R 8 & 2.02 & 2.20 & 2.54 & 2.64 & 2.92 & 3.24 & 3.36 & 3.5 & 248 & 133 \\
\hline $\mathrm{RC}$ & 1.40 & 1.83 & 2.54 & 2.69 & 3.10 & 3.48 & 3.71 & 4.06 & 380 & 117 \\
\hline R 5 & 2.02 & 2.35 & 2.60 & 2.69 & 2.95 & 3.23 & 3.33 & 3.46 & 247 & 131 \\
\hline R 11 & 1.45 & 2.03 & 2.28 & 2.48 & 2.80 & 3.12 & 3.26 & 3.43 & 372 & 143 \\
\hline R 1 & 1.52 & 1.64 & 1.94 & 2.08 & 2.41 & 2.75 & 2.88 & 3.18 & 348 & 187 \\
\hline $\mathrm{CH} 5$ & 2.06 & 2.3 & 2.61 & 2.74 & 3.09 & 3.46 & 3.7 & 4.09 & 240 & 117 \\
\hline $\mathrm{CH} 4$ & 2.12 & 2.53 & 2.73 & 2.89 & 3.22 & 3.50 & 3.87 & 4.31 & 230 & 107 \\
\hline $\mathrm{CH} 3$ & 2.04 & 2.38 & 2.81 & 3.04 & 3.32 & 3.71 & 3.9 & 4.28 & 245 & 101 \\
\hline $\mathrm{CH} 2$ & 2.04 & 2.26 & 2.61 & 2.78 & 3.14 & 3.42 & 3.57 & 3.96 & 243 & 113 \\
\hline $\mathrm{CH} 1$ & 2.01 & 2.08 & 2.29 & 2.46 & 2.79 & 3.18 & 3.36 & 3.772 & 250 & 145 \\
\hline PA5 & -0.40 & 0.96 & 1.70 & 1.97 & 2.56 & 3.50 & 3.79 & 4.23 & 1355 & 170 \\
\hline PA4 & -0.30 & 1.02 & 1.41 & 1.74 & 2.44 & 3.26 & 3.62 & 4.16 & 1245 & 186 \\
\hline PA3 & 0.00 & 0.94 & 1.51 & 1.79 & 2.34 & 3.26 & 3.68 & 4.18 & 1000 & 203 \\
\hline PA2 & -0.10 & 0.65 & 1.20 & 1.48 & 2.13 & 2.83 & 3.29 & 3.98 & 1048 & 230 \\
\hline PA1 & 0.20 & 1.07 & 1.48 & 1.88 & 2.51 & 3.31 & 3.66 & 4.19 & 920 & 177 \\
\hline
\end{tabular}

Where $\mathrm{C}$ is the coarser one- percentile value in micron and $\mathrm{M}$ is the median value in micron. 


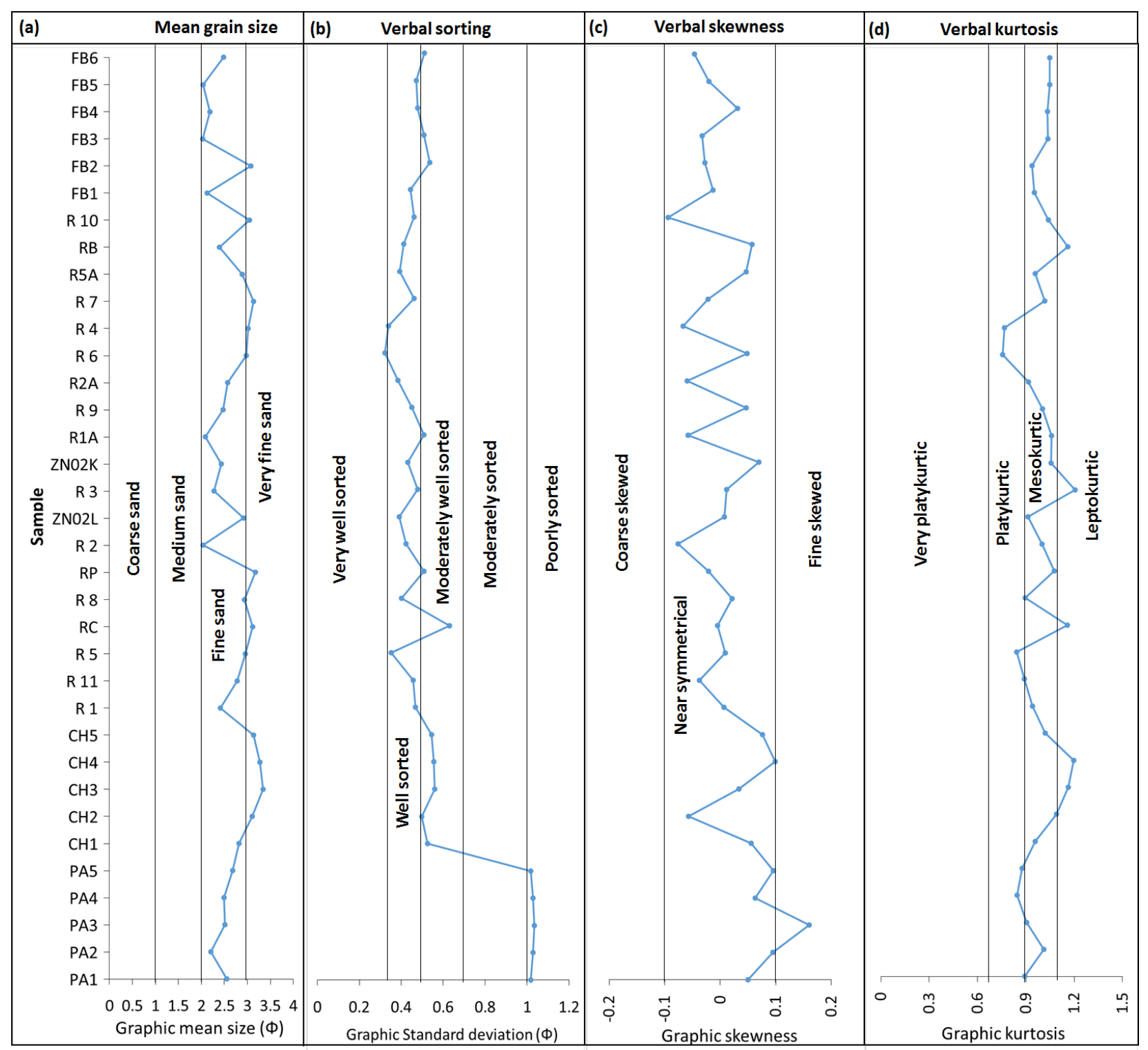

Figure 8: Variation of textural components of the Permian sandstone samples of the Ecca Group (a) Graphic mean; (b) standard deviation; (c) skewness and (d) kurtosis. 
its source or deposited quickly [22]. Most of the Ecca sandstones are fine grained and well sorted meaning they had a reasonable time in the transporting medium and because of the grain to grain interaction, their sizes were perhaps reduced. The Prince Albert Formation is interpreted as deep marine sediment and sandstone that has been found between shales and mudstone. The dominance of poorly sorted sandstones in the Prince Albert Formation may point to a near source region. However, the considerable number of well sorted to moderately well sorted sediments in other formations indicate continuous reworking of the sediments by currents and waves [66]. These fine grained and better sorted sandstones from Prince Albert Formation are thought to have been previously reworked in the shallow-water environments and subsequently brought to the deep marine environment. The plot of standard deviation (sorting) against mean shows clustering of samples near the extreme end of right limb of the inverted V-shaped established trend of [4], signifying a smaller size range of the grains (Figure 9b). Both mean grain size and sorting are hydraulically controlled, such that in all sedimentary environments, the well-sorted sediments have mean size in the fine sand size range [67]. The nature of the Ecca sediments is generally unimodal, of which the dominant constituent is fine sand. The very fine sediment (fine and silty sand) is subordinate making the admixture moderatelysorted.

\subsubsection{Graphic skewness versus mean}

The bivariate plot of graphic skewness versus mean shows that most of Ecca samples are near symmetrical (Figure 10a). Only one sample (PA3) from the Prince Albert Formation is fine skewed. The plot of skewness against mean shows clustering of values near inside the sinusoidal curve of established trend of [4], which also point to a smaller size range of the grains (Figure 10b). The sinusoidal nature of the studied sediments are due to the proportionate admixture of two size-classes of the sediments, i.e. fine sand and very fine silty sand. Again, this agrees with the inverted V-shaped curve of Figure $9 \mathrm{~b}$ as proposed by [4]. In general, the unimodal sediments are nearly symmetrical but the mixing produces either positive or negative skewness depending upon the proportions of size-classes in the admixture.



(a)

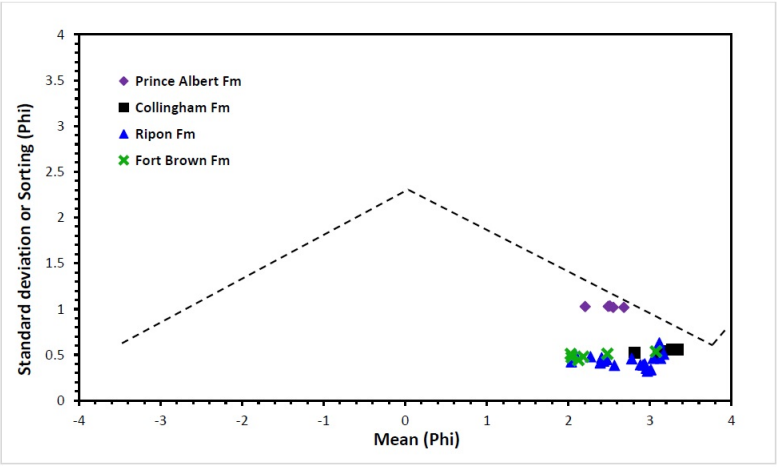

(b)

Figure 9: (a) Bivariate plot of graphic standard deviation versus graphic mean skewness. (b) Bivariate plot of standard deviation versus mean showing the placement of Ecca samples in the model plot as proposed by [4].

\subsubsection{Graphic kurtosis versus mean}

The bivariate plot of graphic kurtosis versus mean shows that the Ecca samples are platykurtic to leptokurtic (Figure 11a). The mesokurtic (0.90-1.11) category dominants, followed by platykurtic (0.67-0.90) and leptokurtic (1.11-1.5) respectively, in the size-class range of approximately 2-3.4 Phi (fine to very fine sand). The relationship between kurtosis and mean-size is complex and theoretical [4]. The plot of kurtosis against mean shows scattering of samples near the base, in the region of normal Kg curve (mesokurtic category) established trend of [4] (Figure 11b). Based on the model plot (Figure 11b), it could be inferred that the scattering led to the mixing of two or more grain size-classes, which basically influenced the sorting in peak and tails (index of kurtosis) as well as the inverted 'V' trend. The grain mixture is dominantly fine-sand and subordinate very fine sand. The proportionate grain mixture makes the 


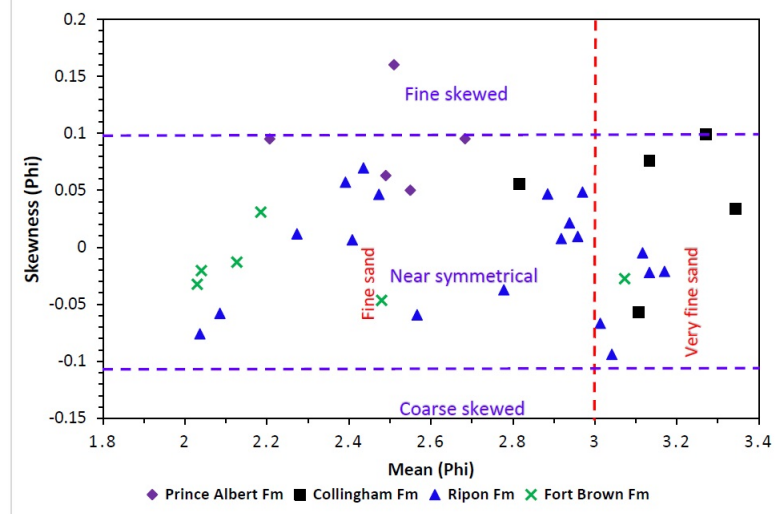

(a)

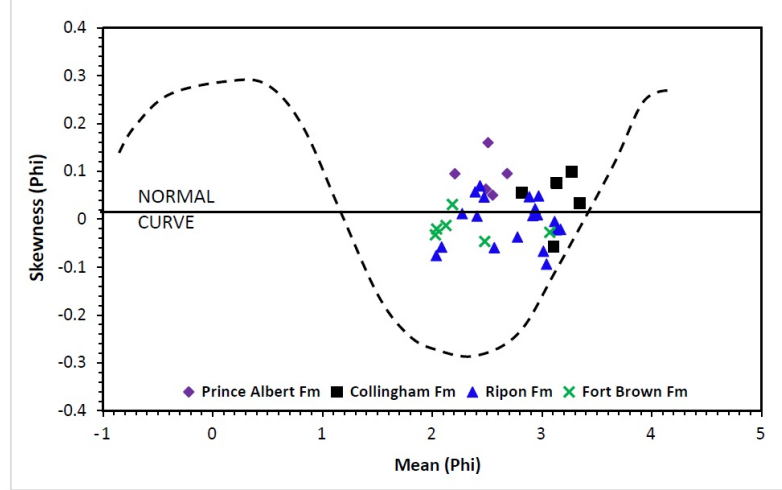

(b)

Figure 10: (a) Bivariate plot of graphic skewness against mean. (b) Bivariate plot of graphic skewness versus mean showing the placement of Ecca samples in the model plot as proposed by [4].

sorting good, with the exception of the Prince Albert Formation. The varying proportions of very fine sediments mixed with dominant fine sand mode reduced the degree of sorting, particularly in the tails; thus, platykurtic to leptokurtic conditions existed.

\subsubsection{Graphic standard deviation (sorting) versus skewness}

The bivariate plot of graphic standard deviation (sorting) versus skewness shows that most of Ecca samples are well sorted and near symmetrical (Figure 12a). However, one sample (PA3) from the Prince Albert Formation is very fine skewed and poorly sorted. The moderately well sorted to moderately sorted sediments are mainly clustered around the near symmetrical. The plot of standard deviation against skewness gives a scattered trend in the form of nearly circular ring (After [4]). This may be due to

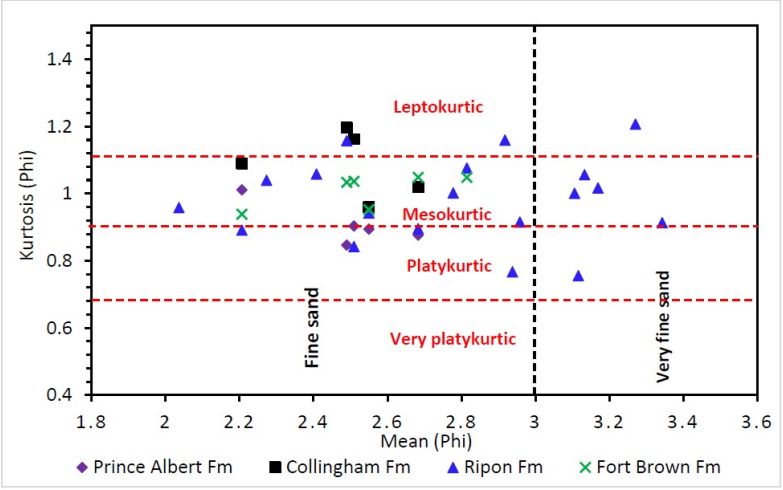

(a)

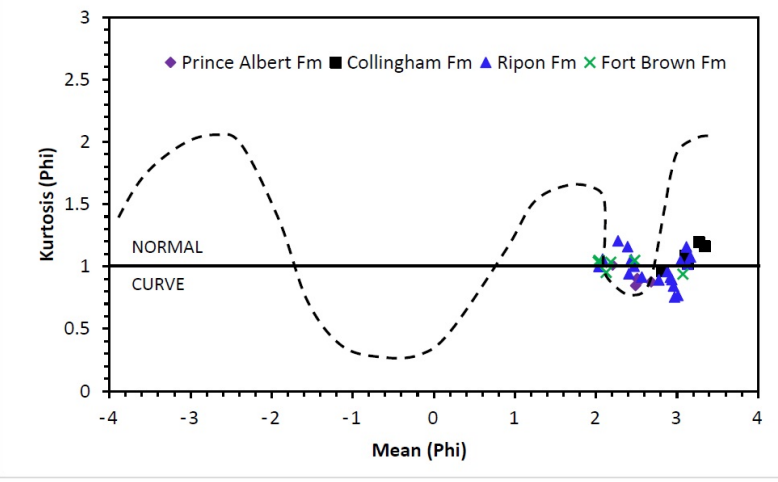

(b)

Figure 11: (a) Bivariate plot of graphic kurtosis against mean. (b) Bivariate plot of graphic kurtosis versus mean showing the placement of Ecca samples in the model plot as proposed by [4].

two conditions i.e. either mixture of two modes in equal proportion in bimodal sediments or good sorting in unimodal sediments. The scattering in Figure $12 \mathrm{~b}$ shows clustering of grains in one sector, which denotes the dominance of fine sand mode having subordinate very fine sediments. The skewness value of sediments from the Ripon Formation are equally deviated around the normal curve $(\mathrm{Sk}=0)$. Collingham samples are slightly positive skewed with higher proportion of fine grained sand except the $\mathrm{CH} 2$, while samples from the Prince Albert Formation have the highest shift toward fine skewed values. In general, this bivariate plot (Figure 12b) suggests, based on the position on the circle (well sorting and generally near symmetry; Sk around 0) that analysed sandstones are generally unimodal samples with good sorting. Samples from the Prince Albert Formation are an exception. 


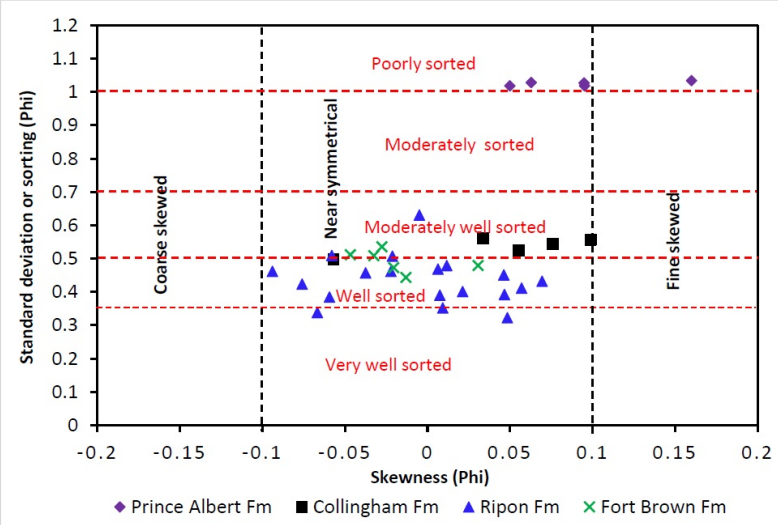

(a)

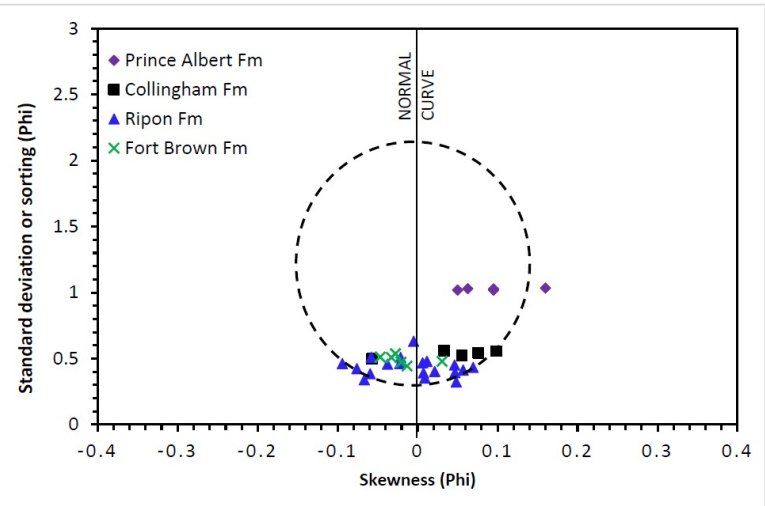

(b)

Figure 12: (a) Bivariate plot of graphic standard deviation against skewness. (b) Bivariate plot of graphic skewness versus standard deviation showing the placement of Ecca samples in the model plot as proposed by [4].

\subsection{Graphic kurtosis versus skewness}

[63] pointed out that the bivariate plot of kurtosis against skewness of a given sediment population is a powerful tool for distinguishing between depositional environments. The bivariate plot of graphic kurtosis versus skewness shows that the Ecca samples are platykurtic to leptokurtic (i.e. mesokurtic in average) and are mostly near symmetrical (Figure 13a). According to [27], extreme high or low values of kurtosis imply that part of the sediment achieved their sorting elsewhere in a high energy environment. The plot of kurtosis versus skewness (Figure 13b) follows a regular path of sinusoidal pattern as the meansize changes and is dependent on two modes [4]. Generally, the Ecca samples plotted in the normal curve (shaded) area, which is represented by nearly pure sand and sandsilt mixture in the establish plot of [4] (Figure 13b).

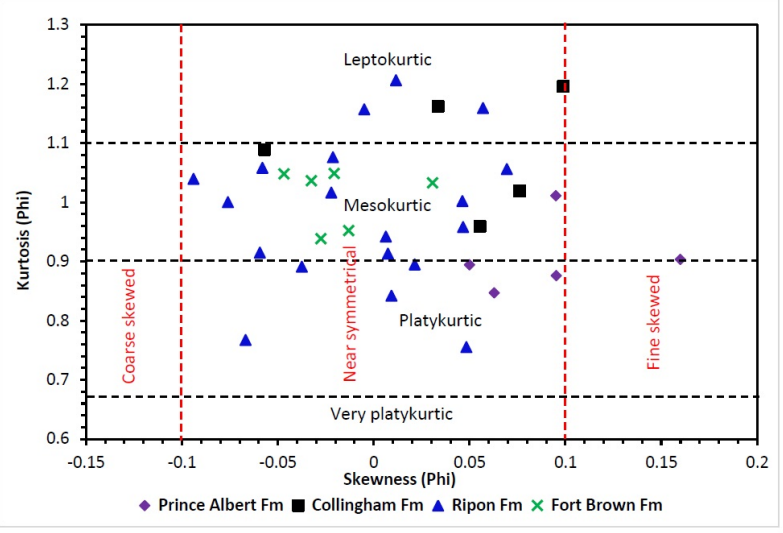

(a)

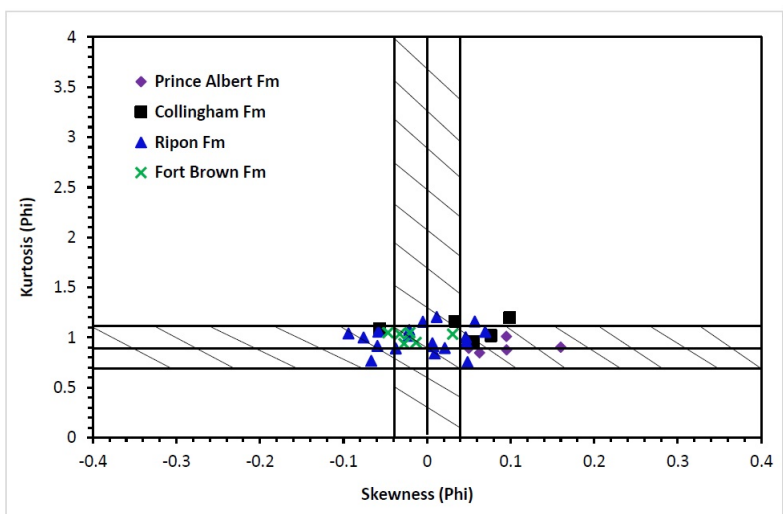

(b)

Figure 13: (a) Bivariate plot of graphic kurtosis versus skewness. (b) Bivariate plot of graphic kurtosis versus skewness showing the placement of Ecca samples in the model plot as proposed by [4].

\subsection{Linear discriminate function (LDF)}

The use of statistical analysis to interpret the variations in energy and fluidity factors during/prior to sediment deposition seems to have a very good correlation with the different processes and depositional environments [7]. The [7] linear discriminant functions of $\mathrm{Y}_{1}$ (shallow agitated water and beach), $\mathrm{Y}_{2}$ (beach and shallow marine), $\mathrm{Y}_{3}$ (shallow marine and deltaic or lacustrine) and $\mathrm{Y}_{4}$ (turbidity and deltaic) were modified and used to discriminate between the different processes and depositional environments. To discriminate between shallow agitated water (SA) and beach (B), equation (i) below was applied:

$Y_{1(S A: B)}=-3.5688 M+3.7016 r^{2}-2.0766 S K+3.1135 K G$

If $Y_{1}$ is $<-2.7411$, the environment is "shallow agitated water" and if $Y_{1}$ is $>-2.7411$, the environment is "beach". 
Equation (ii) was used to distinguish between beach (B) and shallow marine (SM) environments.

$Y_{2(B: S M)}=15.6534 M+65.7091 r^{2}+18.1071 S K+18.5043 K G$

If $Y_{2}$ is $<-63.3650$, the environment is "beach" and if $Y_{2}$ is $>-63.3650$, the environment is "shallow marine".

To distinguish environment of deposition between shallow marine (SM) and deltaic or lacustrine (L), equation (iii) was applied:

$Y_{3(S M: F)}=0.2852 M-8.7604 r^{2}-4.8932 S K+0.0482 K G$

If $Y_{3}$ is $>-7.4190$, the environment is "shallow marine" and if $Y_{3}$ is $<-7.4190$, the environment is "deltaic or lacustrine".

To discriminate between deltaic (D) and turbidity current deposits, equation (iv) below was applied:

$$
Y_{4(F: T)}=0.7215 M-0.4030 r^{2}+6.7322 S K+5.2927 K G
$$

If $Y_{4}$ is $<9.8433$, it indicate turbidity current deposition and if $Y_{4}$ is $>9.8433$, it indicate deltaic deposition. Where $\mathrm{M}$, r, SK, and KG represents mean grain size, standard deviation, skewness and kurtosis, respectively.

After calculating the above mentioned linear discriminate functions $\left(\mathrm{Y}_{1}, \mathrm{Y}_{2}, \mathrm{Y}_{3}\right.$ and $\left.\mathrm{Y}_{4}\right)$ for the Ecca Group samples, it was determined that the values for $\mathrm{Y}_{1}, \mathrm{Y}_{2}, \mathrm{Y}_{3}$ and $\mathrm{Y}_{4}$ range from -7.96 to $-1.02,60.79$ to $133.58,-9.38$ to -0.22 and 6.51 to 12.34 , respectively (Table 6).

Based on the $Y_{1}$ values, all the samples from the Prince Albert, Collingham and Ripon Formations falls in shallow agitated water process, while those from the Fort Brown Formation falls in both the shallow agitated water and beach processes. With reference to the $\mathrm{Y}_{2}$ values, all the Ecca samples fall in the shallow marine environment. In addition, Prince Albert, Collingham and Ripon Formations fall in the $\left(\mathrm{Y}_{3}\right)$ shallow marine environment, while those from the Fort Brown Formation falls in the deltaic or lacustrine environment. With reference to the $\mathrm{Y}_{4}$ values, samples from the Prince Albert, Collingham and Ripon Formations are turbidity current deposits, while those from the Fort Brown Formation are deltaic deposits. The binary plot of $Y_{2}$ versus $Y_{1}$ after [7] showed that most of the Ecca samples fall in the shallow agitated waters/shallow marine, while few samples plotted into the beach/shallow marine environment (Figure 14). Furthermore, the plot of $\mathrm{Y}_{3}$ against $Y_{2}$ (Figure 15) indicates that all the samples from Prince Albert, Collingham and Ripon Formations plotted in the shallow marine environments, while those samples from Fort Brown Formation falls in the deltaic or lacustrine environment. The plot of $Y_{4}$ against $Y_{3}$ (Figure 16) shows

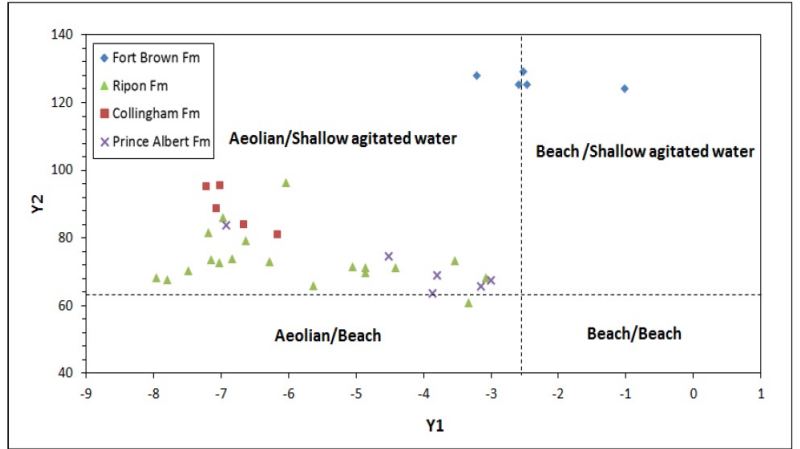

Figure 14: Discrimination of environments based on Linear Discrimination functions (LDF) plot of $Y 2$ against $Y 1$.

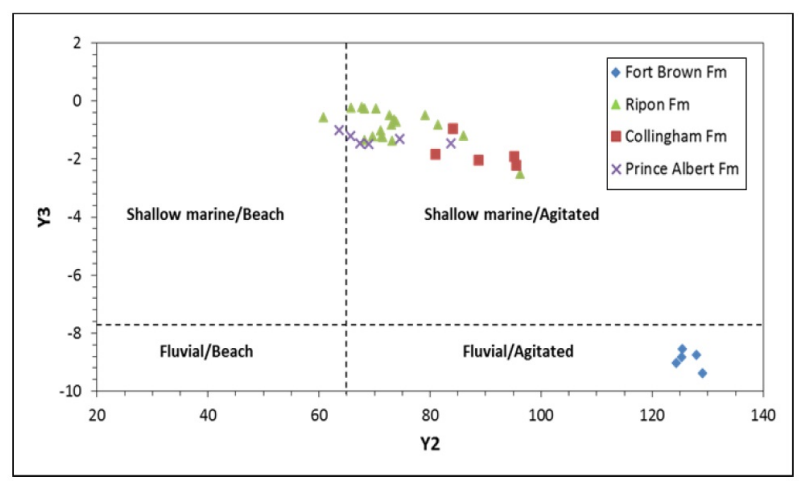

Figure 15: Discrimination of environments based on Linear Discrimination functions (LDF) plot of $Y 3$ against $Y 2$.

that all the samples from Prince Albert, Collingham and Ripon Formations are turbidity current deposits, while those samples from Fort Brown Formation are deltaic or lacustrine deposits.

\subsubsection{Facies analysis}

The use of statistical methods may be helpful in characterizing depositional environment. However, there is need to use other approaches like facies associations, architecture of sediment bodies, bed thicknesses, sedimentary structures and facies fossils. In this study, we cross-check the environments depicted from the grain size parameters with the facies elements. Facies analysis of the Ecca formations were carried out using a modified version of lithofacies classification scheme by Miall's [43, 68, 69]. On a small scale, each of the stratigraphic member or formation is associated with a distinctive sedimentary facies based on their lithological characteristics and sedimentary structures. Fourteen lithofacies were identified by the authors in the five formations of the Ecca Group (Table 7). From 
Table 6: Linear discriminate function (LDF) values and depositional environments for Ecca sandstones calculated after [7].

\begin{tabular}{|c|c|c|c|c|c|c|c|c|}
\hline \multirow[t]{2}{*}{ Sample No. } & \multicolumn{4}{|c|}{$\begin{array}{c}\text { Discriminate } \\
\text { function }\end{array}$} & \multicolumn{4}{|c|}{ Environment of deposition } \\
\hline & Y1 & Y2 & Y3 & Y4 & Y1 & Y2 & Y3 & Y4 \\
\hline FB6 & -3.21 & 128.02 & -8.74 & 12.12 & shallow agitated water & Shallow marine & Deltaic/Lacustrine & Deltaic \\
\hline FB5 & -2.47 & 125.26 & -8.82 & 11.97 & Beach & Shallow marine & Deltaic/Lacustrine & Deltaic \\
\hline FB4 & -2.52 & 129.07 & -9.38 & 12.34 & Beach & Shallow marine & Deltaic/Lacustrine & Deltaic \\
\hline FB3 & -1.02 & 124.27 & -9.03 & 10.83 & Beach & Shallow marine & Deltaic/Lacustrine & Deltaic \\
\hline FB2 & -3.59 & 125.42 & -8.55 & 10.11 & shallow agitated water & Shallow marine & Deltaic/Lacustrine & Deltaic \\
\hline FB1 & -3.87 & 133.58 & -8.11 & 6.56 & shallow agitated water & Shallow marine & Deltaic/Lacustrine & Turbidity \\
\hline $\mathrm{R} 10$ & -6.64 & 79.13 & -0.49 & 7.14 & shallow agitated water & Shallow marine & Shallow marine & Turbidity \\
\hline RB & -4.42 & 71.05 & -1.02 & 8.31 & shallow agitated water & Shallow marine & Shallow marine & Turbidity \\
\hline R5A & -6.84 & 73.84 & -0.71 & 7.53 & shallow agitated water & Shallow marine & Shallow marine & Turbidity \\
\hline R 7 & -7.19 & 81.42 & -0.81 & 7.58 & shallow agitated water & Shallow marine & Shallow marine & Turbidity \\
\hline R 4 & -7.8 & 67.66 & -0.22 & 5.83 & shallow agitated water & Shallow marine & Shallow marine & Turbidity \\
\hline R 6 & -7.96 & 68.17 & -0.26 & 6.51 & shallow agitated water & Shallow marine & Shallow marine & Turbidity \\
\hline $\mathrm{R} 2 \mathrm{~A}$ & -5.64 & 65.74 & -0.23 & 6.35 & shallow agitated water & Shallow marine & Shallow marine & Turbidity \\
\hline R 9 & -5.05 & 71.44 & -1.25 & 7.48 & shallow agitated water & Shallow marine & Shallow marine & Turbidity \\
\hline R1A & -3.07 & 68.17 & -1.34 & 6.82 & shallow agitated water & Shallow marine & Shallow marine & Turbidity \\
\hline ZN02K & -4.86 & 71.18 & -1.23 & 7.89 & shallow agitated water & Shallow marine & Shallow marine & Turbidity \\
\hline R 3 & -3.53 & 73.18 & -1.36 & 8.2 & shallow agitated water & Shallow marine & Shallow marine & Turbidity \\
\hline ZN02L & -7.03 & 72.7 & -0.49 & 7.04 & shallow agitated water & Shallow marine & Shallow marine & Turbidity \\
\hline $\mathrm{R} 2$ & -3.33 & 60.79 & -0.57 & 6.32 & shallow agitated water & Shallow marine & Shallow marine & Turbidity \\
\hline $\mathrm{RP}$ & -6.97 & 86.03 & -1.19 & 7.94 & shallow agitated water & Shallow marine & Shallow marine & Turbidity \\
\hline R 8 & -7.15 & 73.49 & -0.63 & 7.06 & shallow agitated water & Shallow marine & Shallow marine & Turbidity \\
\hline $\mathrm{RC}$ & -6.04 & 96.22 & -2.51 & 8.4 & shallow agitated water & Shallow marine & Shallow marine & Turbidity \\
\hline R 5 & -7.49 & 70.19 & -0.25 & 6.7 & shallow agitated water & Shallow marine & Shallow marine & Turbidity \\
\hline R 11 & -6.29 & 73.03 & -0.81 & 6.55 & shallow agitated water & Shallow marine & Shallow marine & Turbidity \\
\hline R 1 & -4.86 & 69.66 & -1.22 & 6.85 & shallow agitated water & Shallow marine & Shallow marine & Turbidity \\
\hline $\mathrm{CH} 5$ & -7.07 & 88.7 & -2.02 & 8.28 & shallow agitated water & Shallow marine & Shallow marine & Turbidity \\
\hline $\mathrm{CH} 4$ & -7.01 & 95.43 & -2.2 & 9.4 & shallow agitated water & Shallow marine & Shallow marine & Turbidity \\
\hline $\mathrm{CH} 3$ & -7.22 & 95.08 & -1.91 & 8.92 & shallow agitated water & Shallow marine & Shallow marine & Turbidity \\
\hline $\mathrm{CH} 2$ & -6.66 & 84.02 & -0.95 & 7.72 & shallow agitated water & Shallow marine & Shallow marine & Turbidity \\
\hline $\mathrm{CH} 1$ & -6.16 & 80.92 & -1.83 & 7.59 & shallow agitated water & Shallow marine & Shallow marine & Turbidity \\
\hline PA5 & -4.52 & 74.54 & -1.3 & 7.63 & shallow agitated water & Shallow marine & Shallow marine & Turbidity \\
\hline PA4 & -3.15 & 65.63 & -1.22 & 7.13 & shallow agitated water & Shallow marine & Shallow marine & Turbidity \\
\hline PA3 & -3.8 & 68.92 & -1.48 & 8.1 & shallow agitated water & Shallow marine & Shallow marine & Turbidity \\
\hline PA2 & -3 & 67.33 & -1.47 & 8.01 & shallow agitated water & Shallow marine & Shallow marine & Turbidity \\
\hline PA1 & -6.93 & 83.77 & -1.45 & 7.33 & shallow agitated water & Shallow marine & Shallow marine & Turbidity \\
\hline
\end{tabular}




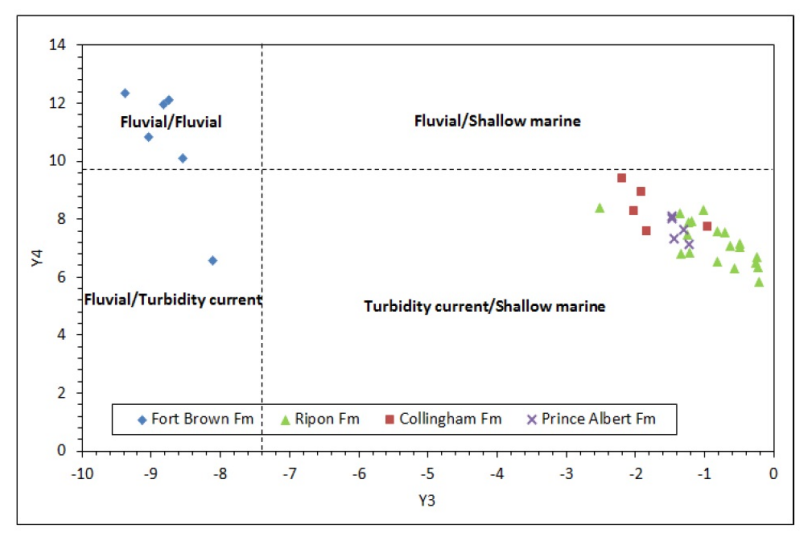

Figure 16: Discrimination of environments based on Linear Discrimination functions (LDF) plot of $Y 4$ against $Y 3$.

the bottom to the top of the Group, the identified lithofacies are: dark-grey medium to thick bedded shale, greyish mudstone and claystone turbidite, black laminated to thin bedded shale with lenticular siltstone, laminated shale intercalated with mudstone and lenticular siltstone, greyish laminated shale intercalated with lenticular chert, greyish laminated mudstones rhythmite, greyish laminated to thin bedded mudstone and lenticular siltstone, greyish laminated to thin bedded shale, dark thin bedded bioturbated mudstone, black thin to medium bedded carbonaceous mudstone, ripple cross-laminated sandstone, greyish lenticular and thin bedded sandstones, thin to medium bedded sandstone alternated with thin bedded mudstone and thin to medium bedded sandstone interbedded with laminated shale. In order to depict the depositional environment, these fourteen lithofacies were grouped into seven distinct facies associations (Figure 17).

From the bottom to to the top, the facies associations are: shale and mudstones intercalated with siltstones (FA 1; Prince Albert Formation), carbonaceous shale, mudstone with subordinate chert and sandstone (FA 2; Whitehill Formation), mudstones rhythmite with thin bedded mudstone and lenticular siltstone (FA 3; Collingham Formation), greyish medium bedded sandstone intercalated with laminated mudstone (FA 4; Pluto Vale Member of the Ripon Formation), dark-grey medium to thick bedded mudstone and siltstone (FA 5; Wonderfontein Shale Member of the Ripon Formation), thin to medium bedded sandstone alternated with thin bedded carbonaceous mudstone (FA 6; Trumpeters Member of the Ripon Formation) and varved mudstone rhythmite intercalated with sandstone (FA 7; Fort Brown Formation). Based on the lithofacies analyses, it can be inferred that the basal two formations of the Ecca Group (Prince Albert and Whitehill Formations) represents deep marine plain/floor pelagic de- posits, whereas the overlying Collingham Formation represents continental slope outer fan turbidite deposits. The Ripon Formation which can be subdivided into three members represent alternated deep to shallow marine environment, mainly continental slope distal outer fan turbidites, continental slope midfan turbidites, and continental shelf proximal turbidites respectively. The overlying Fort Brown Formation represents fresh water lacustrine deposits.

Sedimentological and sequence stratigraphic evidence revealed that the Ecca Group has progressively changed upward from deep marine environment to shallow marine environment, and finally to freshwater lacustrine environment, which implies that the Main Karoo Basin was gradually filling up with Ecca sediments resulting in the gradual shallowing up of the water depth of the depositional basin. It is observed that the depostional environments deduced from grain size parameters agrees to an extent with those from sedimentary facies analysis. The weakness in the grain-size analysis is that the samples from the Prince Albert and Whitehill Formations plot in the shallow marine environment whereas these formations are purely deep marine sediments based on the facies architecture. On the otherhand, the Collingham and Ripon Formations are turbidites (turbidity current deposits) while the overlying Fort Brown Formation is lacustrine deposit as indicated by both facies architecture and grain-size approaches. This also agrees with the findings of [40] that the deeper marine facies of the early Ecca Group were accumulated during the under-filled phase of the foreland system, whereas the shallow marine facies of the late Ecca Group correspond to the filled phase of the basin, which was followed by an overfilled phase dominated by fluvial sedimentation of the Beaufort Group. The main weakness in the use of grain-size analysis to decipher depositional environments is that the approach does not distinguish between deep and shallow marine settings.

\subsection{Passega diagram (CM pattern)}

[5] introduced the use of C-M plot to decipher the hydrodynamic forces that works or prevails during sediment deposition. The C-M plot is a binary plot of coarser one- percentile value (C) in micron against the median value (M) in micron on a log-probability scale (Table 5). The relationship between $C$ and $M$ is linked to the nature of the several sediment types and energy of the transportation medium $[6,10]$. The Passega diagram depicted in Figure 18 shows several fields (rolling-NO, rolling and suspension$\mathrm{OP}$, suspension and rolling-PQ, graded suspension- $\mathrm{QR}$, uniform suspension-RS, and pelagic suspension-T) that 
Table 7: Lithofacies identified in the Ecca Group.

\begin{tabular}{|c|c|c|}
\hline Facies Code & Facies & Sedimentary Structures \\
\hline SFt & $\begin{array}{l}\text { Thin to medium bedded } \\
\text { sandstone interbedded with } \\
\text { laminated shale }\end{array}$ & $\begin{array}{l}\text { Thin to medium bedded, trough cross-bedding, and } \\
\text { sometimes with deformational structures }\end{array}$ \\
\hline SFm & $\begin{array}{l}\text { Thin to medium bedded } \\
\text { sandstone alternated with thin } \\
\text { bedded mudstone }\end{array}$ & $\begin{array}{l}\text { Thin to medium bedded, horizontal lamination, } \\
\text { micro-cross lamination, current ripple cross-lamination, } \\
\text { wavy lamination, graded bedding }\end{array}$ \\
\hline Slt & Greyish lenticular and thin & Fine grained, lenticular bedding \\
\hline Srl & Ripple cross-laminated sandstone & $\begin{array}{l}\text { Fine grained with ripple marks, or ripple lamination, } \\
\text { sometimes with climbing ripple marks and low angle } \\
\left(<10^{\circ}\right) \text { cross- lamination }\end{array}$ \\
\hline $\mathrm{Fc}$ & $\begin{array}{l}\text { Black thin to medium bedded } \\
\text { carbonaceous mudstone }\end{array}$ & $\begin{array}{l}\text { Thin to medium bedded, rich organic carbon or } \\
\text { carbonized plant matter }\end{array}$ \\
\hline $\mathrm{Fbm}$ & $\begin{array}{l}\text { Dark thin bedded bioturbated } \\
\text { mudstone }\end{array}$ & Thin bedded, roots, bioturbation \\
\hline Fls & $\begin{array}{l}\text { Greyish laminated to thin bedded } \\
\text { shale }\end{array}$ & Laminated to thin bedded, pencil cleavage \\
\hline Fms & $\begin{array}{l}\text { Greyish laminated to thin bedded } \\
\text { mudstone and lenticular siltstone }\end{array}$ & $\begin{array}{l}\text { Laminated, thin bedded, low angle cross bedding, } \\
\text { deformational convolute bedding, folding structures }\end{array}$ \\
\hline Frh & $\begin{array}{l}\text { Greyish laminated mudstones } \\
\text { rhythmite }\end{array}$ & $\begin{array}{l}\text { Fine lamination to thin bedded, with laminae consisting } \\
\text { of alternating light and dark coloured mudstone layers }\end{array}$ \\
\hline Fsc & $\begin{array}{l}\text { Greyish laminated shale } \\
\text { intercalated with lenticular chert }\end{array}$ & Fine grained, thin laminated with lenticular bedding \\
\hline Fsm & $\begin{array}{l}\text { Laminated shale intercalated with } \\
\text { mudstone and lenticular siltstone }\end{array}$ & $\begin{array}{l}\text { Horizontally well-laminated, lenticular bedding, rich in } \\
\text { organic carbon as well as iron sulphide (pyrite). }\end{array}$ \\
\hline Fss & $\begin{array}{l}\text { Black laminated to thin bedded } \\
\text { shale with lenticular siltstone }\end{array}$ & $\begin{array}{l}\text { Well laminated to thin bedded, lenticular bedding, } \\
\text { sometimes with minor fine sandstone lenses and very } \\
\text { small ripples }\end{array}$ \\
\hline Ftb & $\begin{array}{l}\text { Greyish mudstone and claystone } \\
\text { turbidite }\end{array}$ & $\begin{array}{l}\text { Varve bedded, fine lamination, micro-ripple laminations, } \\
\text { climbing ripple lamination, convolute lamination and } \\
\text { erosional wave mark structures, occasionally with faint } \\
\text { striation and feebly grade bedding }\end{array}$ \\
\hline Fts & $\begin{array}{l}\text { Dark-grey medium to thick } \\
\text { bedded shale }\end{array}$ & $\begin{array}{l}\text { Medium to thick bedded, massive beds sometimes } \\
\text { faintly laminated and graded }\end{array}$ \\
\hline
\end{tabular}




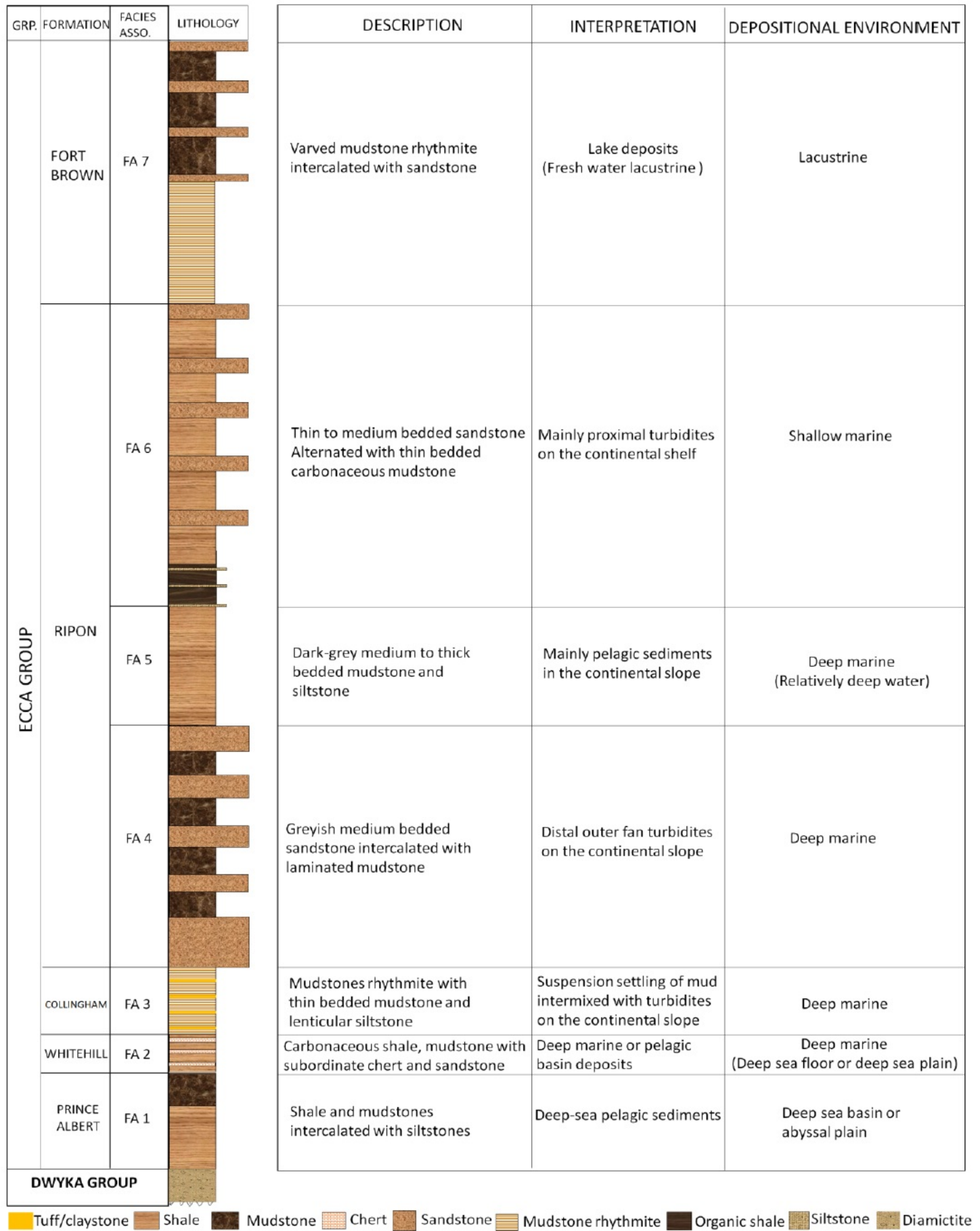

Figure 17: Lithologic interpretation of the facies association in the Ecca Group (After [35]). 
correspond to the various transport and sedimentation conditions in the marine and littoral/fluvial environments. The plot of $C$ against $M$ values (Table 5) on the Passega diagram (Figure 18) shows that all the samples from the Prince Albert Formation plotted in the rolling and suspension condition (OP), while those from the Collingham Formation falls in the graded suspension $(\mathrm{QR})$ section. Samples from the Ripon and Fort Brown Formations are scattered in both the suspension and rolling $(\mathrm{PQ})$ and graded suspension $(\mathrm{QR})$ sections. The C-M plot showing depositional environment (Figure 19) indicate that the Ecca sediments were deposited by turbidity currents. Similar CM patterns are also documented for the Gondwana sandstone in the Godavari Basin [70, 71] as well as the Kamthi Sandstone [72, 73]. Modern rivers like Gomti River [74] and Gadilam River Basin [75] also shows the same trend. Furthermore, this trend also agrees with the pattern determined by [60] for the coastal sands of Kakapallam area, Marakkanam coast, Tamil Nadu.

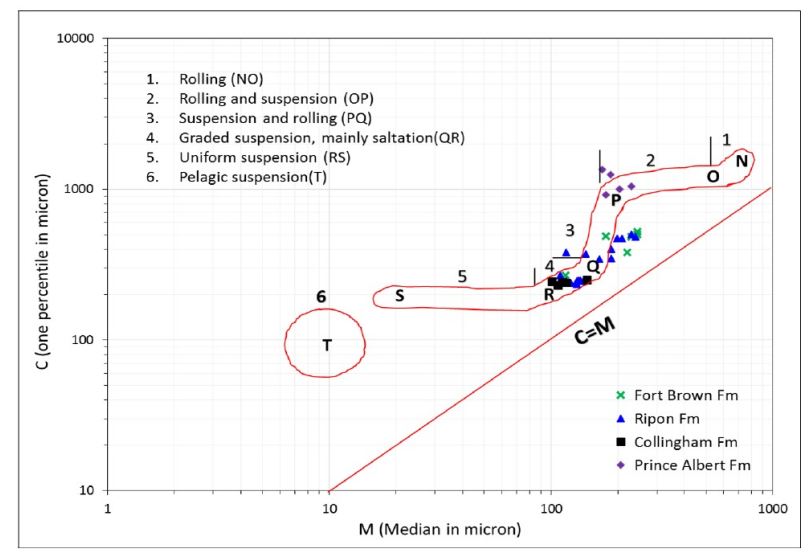

Figure 18: C-M plot showing the transporting mechanism of the Ecca sediments (After [5]).

\subsection{Visher diagram}

The log-probability curves suggested by [10] was used to differentiate between the Ecca Group sediments based on their mechanism of transportation (i.e. traction, saltation and suspension). Visher plot for sediments from the Prince Albert Formation (Figure 20) clearly shows the dominance of double saltation populations (saltaton I and saltation II) with single suspension and traction population (maximum of about $3 \%$ ). The suspension and saltation populations may range up to $30 \%$ and $75 \%$, respectively. Figure 21 also indicates the presence of a double salta-

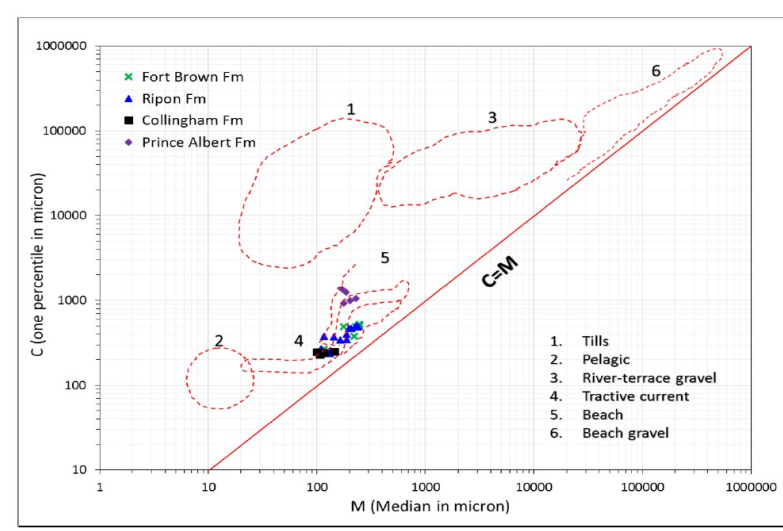

Figure 19: C-M plot showing depositional environment of the Ecca sediments (After [5]).

tion populations and a single suspension population for the Collingham Formation. Furthermore, the Visher plot for sediments from the Ripon Formation (Figure 22) shows the presence of a double saltation populations and single suspension characteristics. The saltation populations are comparatively better sorted than the suspension population. Figure 23 clearly shows the dominance of double saltation populations and single suspension for the Fort Brown samples. However, one of the samples show very little traction population (about $1 \%$ ) around $1 \varnothing$ value. The suspension and saltation populations could be up to $25 \%$ and $85 \%$ respectively. The traction represents minor quantity of poorly-sorted sediments, while the saltation populations are relatively better sorted than the fine-grained suspension population. The double saltation populations truncated mostly between $1.5 \varnothing$ and $2.5 \varnothing$, which could be attributed to internal forces that is causing sliding or rolling [10]. The breaks in the log-probability curves for the Prince Albert Formation is not as sharp compared to other formations, which could be due to mixing of detritus carried by tractive currents with different energy [76] or they may have been sourced from different provenances.The log probability curves presented in this study are comparable with well-known trends for modern and ancient lacustrine/fluvial deposits as suggested by [10], in which both saltation and suspension populations dominated.

\section{Conclusions}

Grain-size analysis of thirty-five Permian Ecca sandstone samples has been carried out. The important conclusions drawn are as follows: 


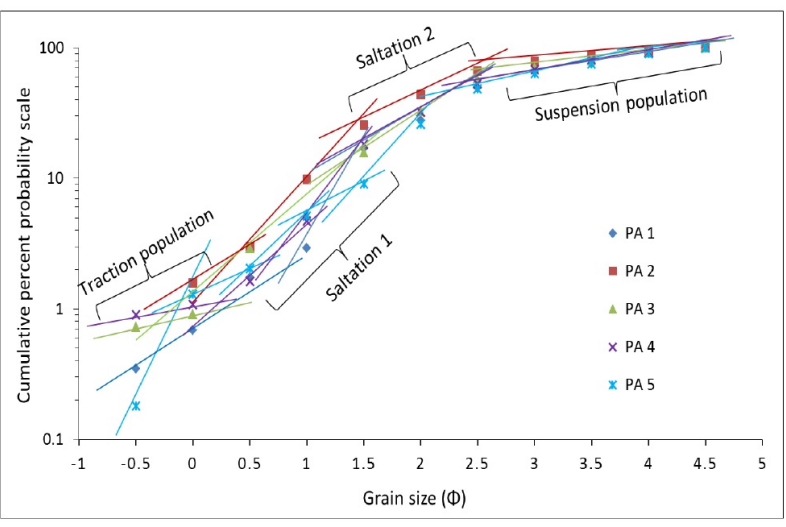

Figure 20: Arithmetic probability curves showing the trend of traction, saltation and suspension populations of the Prince Albert Formation samples.

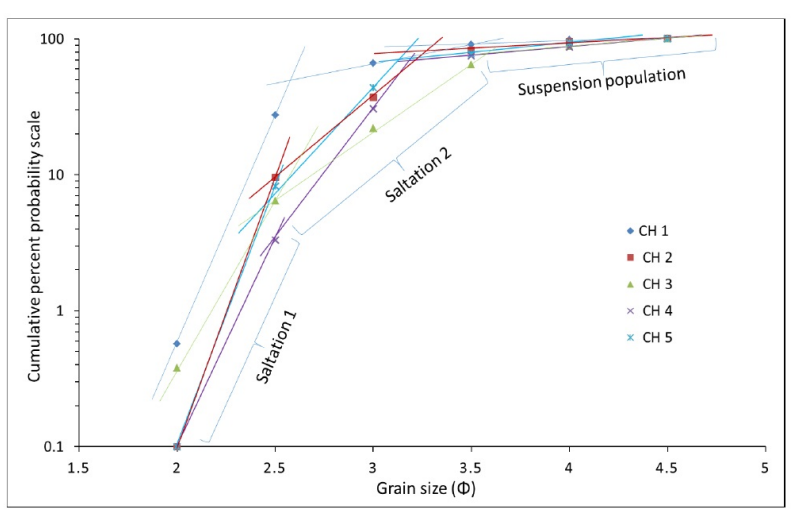

Figure 21: Arithmetic probability curves showing the trend of saltation and suspension populations of the Collingham Formation samples.

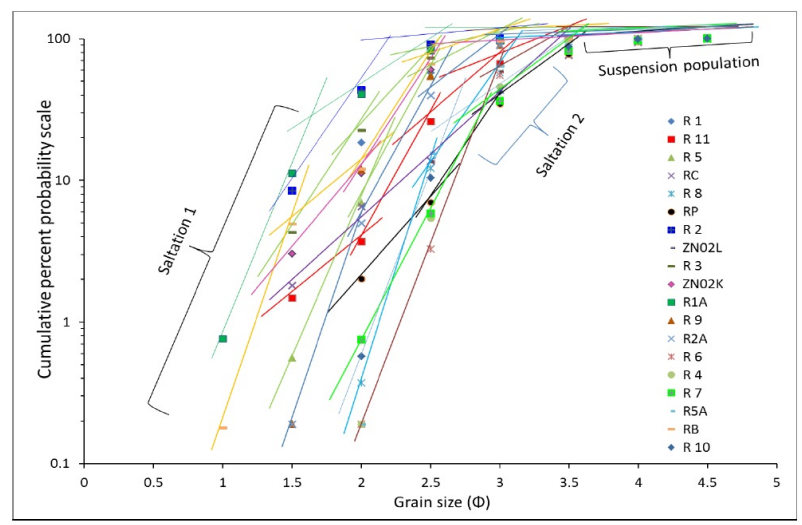

Figure 22: Arithmetic probability curves showing the trend of saltation and suspension populations of the Ripon Formation samples.

- The cumulative weight percentage frequency curves and whole grain size statistics are mainly indicative of very fine to fine-grained nature of the sediments.

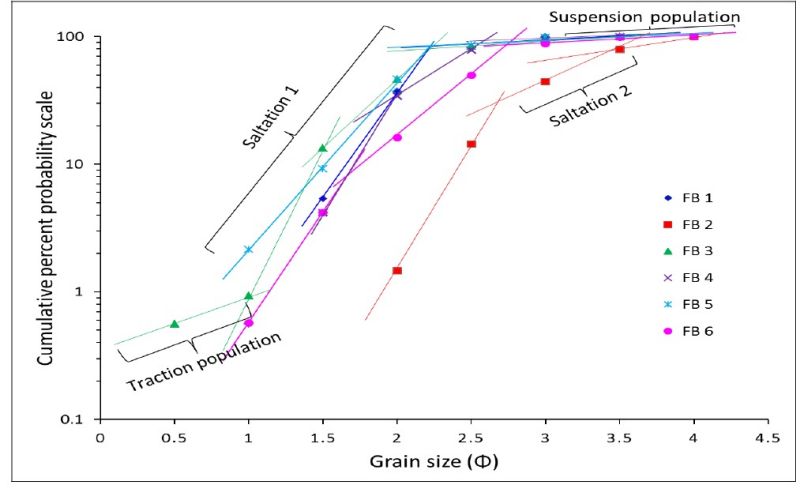

Figure 23: Arithmetic probability curves showing the trend of traction, saltation and suspension populations of the Fort Brown Formation samples.

In addition, most of the sandsones show unimodal of grain-size distribution.

- The average sorting of all sandstones is 0.543 (moderately well sorting) and are mostly near-symmetrical in nature. Generally, the moderately well sorted nature of the sediment could be due to partial winnowing action as well as the addition or influx of previously sorted sediments in marine environment. In most cases, both peak and tails are equally sorted resulting in the mesokurtic in grain-size partten.

- The modified linear discriminant functions (LDF) analyses are dominantly indicative of turbidity current deposits under deep to shallow marine environments for samples from the Prince Albert, Collingham and Ripon Formations, while those samples from the Fort Brown Formation are lacustrine or deltaic deposits.The use of grain-size analysis does not allow to distinguish between deep and shallow marine settings.

- The graphic mean value shows the dominance of fine sand-size particles, which point to relatively low energy conditions of deposition. The linear discriminant functions (LDF) results point to low energy conditions during the deposition of the Prince Albert, Collingham and part of the Ripon Formation (Pluto Vale and Wonderfontein Shale Members), whereas the Trumpeters Member of the Ripon Formation and the overlying Fort Brown Formation accumulated under high energy conditions.

- The CM pattern shows a clustered distribution of sediments in the $P Q$ and $Q R$ segments, indicating that the sediments were deposited mostly by suspension and rolling/saltation, and graded suspension. Furthermore, the plots also show that the Ecca sediments are mainly deposited by turbidity currents. 
- The log probability curves indicate the variability of hydraulic depositional conditions for the Permian Ecca Group sandstones.Saltation is the major process of transportation, although suspension and traction also played some role during deposition of the sediments. The sediments were mainly in saltation and suspension before being deposited.

Acknowledgement: The authors are grateful to the University of Fort Hare and National Research Foundation of South Africa for financial support (UID: 101980).We thank the editors and anonymous reviewers for their constructive comments, which helped us to improve the manuscript.

\section{References}

[1] Boggs S. Jr., Petrology of Sedimentary Rocks, Second Edition. Cambridge University Press, UK, 2009

[2] Edwards A.C., Grain size and sorting in modern beach sands. Journal of Coastal Research, 2001, 17, 38-52

[3] Blott S.J., Pye, K., GRADSTAT: A Grain Size Distribution and Statistics Package for The Analysis of Unconsolidated Sediments. Earth Surface Process. Landforms, 2001, 26, 1237-1248

[4] Folk R.L., Ward W., Brazos river bar: a study in the significance of grain size parameters. Journal of Sedimentary Petrology, 1957, 27, 3-26

[5] Passega R., Texture as characteristics of clastic deposition. American Association of Petroleum Geologists Bulletin, 1957, 41, 1952-1984

[6] Passega R., Grain size representation by C-M pattern as a geological tool. Journal of Sedimentary Petrology, 1964, 34, 830847

[7] Sahu B.K., Depositional mechanism from the size analysis of elastic sediments. Journal of Sedimentary petrology, 1964, 34(1), 73-83

[8] Folk R.L., A review of grain-size parameters. Sedimentology, 1966, 6, 73-93

[9] Folk R.L., Petrology of sedimentary rocks: Hemphill Publishing Co., Austin TX, 1974

[10] Visher G.S., Grain size distributions and depositional processes. Journal of Sedimentary Petrology, 1969, 39,1074-1106

[11] Friedman G.M., Differences in size distribution of populations of particles among sands of various origin. Sedimentology, 1979, 26, 859-862

[12] Pettijohn F J, Potter P E, Siever R., Sand and Sandstone (second edn), New York: Springer-Verlag, 1987

[13] Skaberne D., Interpretation of Depositional Environment Based on Grain Size Distribution of Sandstones of the Val Gardena Formation in the Area Between Cerkno and Smrečje, Slovenia. Geologija, 1996, 39, 193-214

[14] Bhat M.S., Chavadi,V.C., Hegde, V.S., Morphological and textural characteristics of Kudle beach, Karnataka, central west coast of India. Lour.Geol.Soc.India, 2002, 59, 125-131
[15] Selvaraj K., Ram Mohan V., Textural Variation and Depositional Environments of Innershelf Sediments, off Kalpakkam, Southeast Coast of India. Journal Geological Society of India, 2003, 61, 449-462

[16] Rao T.C.S., Machado X.T., Murthy K.S.R., Topographic features over the continental shelf off Visakhapatnam. Mahasagar-Bull. Nat. Oceanogr., 1980, 13, 83-89

[17] Angusamy N., Rajamanickam, G. V., Depositional environment of sediments along the southern coast of Tamil Nadu, India. Oceanologia, 2006, 48 (1), 87-102

[18] Kovacs J., Grain-size analysis of the Neogene red clay formation in the Pannonian Basin. Int J Earth Sci (Geol Rundsch), 2008, 97, 171-178

[19] Srivastava A. K., Mankar R.S., Grain Size Analysis and Depositional Pattern of Upper Gondwana Sediments(Early Cretaceous) of Salbardi Area, Districts Amravati, Maharashtra and Betul, Madhya Pradesh. Journal Geological Society of India, 2009, 73, 393-406

[20] Goswami B., Ghosh D., Understanding the transportational and depositional setting of Panchet Formation, Purulia and Bankura districts of West Bengal, India - Evidence from grain size analysis. Front. Earth Sci., 2011, 5(2), 138-149

[21] Srivastava A. K., Ingle P. S., Lunge H. S., Khare N., Grain-size characteristics of deposits derived from different glacigenic environments of the Schirmacher Oasis, East Antarctica. Geologos, 2012, 18(4), 251-266

[22] Rajganapathi V. C., Jitheshkumar N., Sundararajan M., Bhat K. H., Velusamy S., Grain size analysis and characterization of sedimentary environment along Thiruchendur coast, Tamilnadu, India. Arab J Geosci., 2013, 6, 4717-4728

[23] Kulkarni S.J., Deshbhandari P.G., Jayappa K.S., Seasonal Variation in Textural Characteristics and Sedimentary Environments of Beach Sediments, Karnataka Coast, India. Aquatic Procedia, 2015, 4, 117-124

[24] Madukwe H. Y., Granulometric Analysis Of The Sandstone Facies Of The Ise Formation, Southwestern Nigeria. Journal of Multidisciplinary Engineering Science and Technology (JMEST), 2016, 3(2), 3909-3919

[25] Boggs S., Principles of Sedimentology and Stratigraphy, 2nd ed., Prentice Hall, Upper Saddle River, NJ, 1995

[26] Tucker, M. E., Sedimentary Petrology, 3rd ed., Blackwell Publishing Company, Oxford, 2001

[27] Friedman G.M., Distinction between dune, beach and river sands from their textural characteristics. Journal of Sedimentary Petrology, 1961, 31, 514-529

[28] Sagoe K. M. O., Visher G. S., Population breaks in grain-size distributions of sand - a theoretical model. J. Sediment Petrol, 1977, 47(1), 285-310

[29] Catuneanu O., Wopfner H., Eriksson P.G., Cairncross B., Rubidge B.S., Smith R.M.H., Hancox P.J., The Karoo basins of southcentral Africa. Journal of African Earth Sciences, 2005, 43, 211253

[30] Sutherland R.A., Lee C., Discrimination between coastal subenvironments using textural characteristics. Sedimentology, 1994, 41, 1133-1145

[31] Martins L. R., Recent sediments and grain-size analysis. Gravel, 2003, 1, 90-105

[32] Srivastava A.K., Khare N., Ingle P.S., Textural characteristics, distribution pattern and provenance of heavy minerals in glacial sediments of Schirmacher Oasis, East Antarctica. Journal of the 
Geological Society of India, 2010, 75, 393-402

[33] Catuneanu O., Hancox P. J., Rubidge, B.S., Reciprocal flexural behaviour and contrasting stratigraphies: a new basin development model for the Karoo retroarc foreland system, South Africa. Basin Research, 1998, 10, 417-439

[34] Smith R.M.H., Ericksson P.G., Botha W.J., A review of the stratigraphy and sedimentary environments of the Karoo-aged basins of Southern Africa. Journal of African Earth Sciences, 1993, 16 (132), 143-169

[35] Johnson M.R., van Vuuren C.J., Visser J.N.J., Cole D.I., Wickens H. de V., Christie A.D.M., Roberts D.L and Brandl G., Sedimentary Rocks of the Karoo Supergroup. In: Johnson, M.R., Anhaeusser, C.R. and Thomas, R.L. (Eds.), The Geology of South Africa. Geological Society of South Africa, Johannesberg/Council for Geoscience, Pretoria, 2006, 461-499

[36] Smith R.M.H., A review of the stratigraphy and sedimentary environments of the Karoo basin of South Africa. J. Afr. Earth Sci. 1990, 10, 117-137

[37] Johnson M.R., Sandstone petrography, provenance and plate tectonic setting in Gondwana context of the south-eastern Cape Karoo basin. South African Journal of Geology, 1991, 94, 137-154

[38] SACS (South African Committee for Stratigraphy), Stratigraphy of South Africa. Part 1: Lithostratigraphy of the Republic of South Africa, South West Africa/Namibia and the Republics of Bophuthatswana, Transkei and Venda (Compiled by Kent, L.E.). Geological Survey of South Africa. Handbook 8, 1980

[39] Johnson M.R., van Vuuren C.J., Hegenberger W.F., Key R., Show U., Stratigraphy of the Karoo Supergroup in southern Africa: an overview. Journal of African Earth Sciences, 1996, 23, 3-15

[40] Catuneanu O., Elango H.N., Tectonic control on fluvial styles: the Balfour Formation of the Karoo Basin, South Africa. Sedimentary Geology, 2001, 140, 291-313

[41] Johnson M., van Vuuren C., Visser J., Cole D., de Wickens H., Christie A., Roberts D., The Foreland Karoo Basin, South Africa., In: R. Selley (Editor). African Sedimentary Basins of the World, Elsevier, Amsterdam, 1997, 3, 269-317

[42] Catuneanu O., Hancox P.J., Cairncross B., Rubidge B.S., Foredeep submarine fans and forebulge deltas: orogenic off-loading in the underfilled Karoo Basin. Journal of African Earth Sciences, 2002, 35, 489-502

[43] Miall, A. D., The Geology of Fluvial Deposits: Sedimentary Facies, Basin Analysis and Petroleum Geology, Springer, New York, NY, USA, 1996

[44] Kingsley C.S., A composite submarine fan-delta-fluvial model for the Ecca and lower Beaufort Groups of Permian age in the Eastern Cape Province, South Africa. Trans. geol. Soc. S. Afr., 1981, 84, 27-40

[45] De Wit M.J., Ransome I.G., Regional inversion tectonics along the southern margin of Gondwana. In: De Wit, M.J. and Ransome, I.G. (Ed), Inversion tectonics of the Cape Fold Belt, Karoo and Cretaceous Basins of Southern Africa. Rotterdam, 1992, 15 22

[46] Thomas R.J., von Veh M.W., McCourt S., The tectonic evolution of southern Africa: an overview. Journal of African Earth Sciences, 1993, 16(1/2), 5-24

[47] Veevers J.J., Cole D.I., Cowan E.J., Southern Africa: Karoo Basin and Cape Fold Belt. In: J.J. Veevers and C. McA. Powell (Editors). Permian-Triassic Pangean Basins and Foldbelts along the Panthalassan Margin of Gondwanaland. Boulder Colorado. Geological Society of America Memoir, 1994, 184, 223-279
[48] Smith R.M.H., Changing fluvial environments across the Permian-Triassic boundary in the Karoo Basin, South Africa, and possible causes of tetrapod extinctions. Palaeogeography, Palaeoclimatology, Palaeoecology, 1995, 117, 81-104

[49] Trewin N.H, Macdonald D.I.M., Thomas C.G.C., Stratigraphy and sedimentology of the Permain of the Falkland islands: Lithostratigraphic and palaeoenvironmental links with South Africa. Journal of the Geological Society, London, 2002, 159, 5-19

[50] Johnson M.R., Permian Ecca Group (Karoo Supergroup). South African Committee for stratigraphy, Catalogue of South African lithostratigraphic units, 2009, 10, 5-7

[51] Wild R., Flint S., Hodgson D., Stratigraphic evolution of the upper slope and shelf edge in the Karoo Basin. South Africa. Basin Research, 2009, 21, 502-527

[52] Tankard A., Welsink H., Aukes P., Newton R., Stettler E., Tectonic evolution of the Cape and Karoo basins of South Africa. Marine and Petrol. Geol., 2009, 26, 1379-1412

[53] Geel C., Schulz H., Booth P., De Wit M., Horsfield B., Shale gas characteristics of Permian black shales in South Africa: results from recent drilling in the Ecca Group (Eastern Cape). Energy Procedia, 2013, 40, 256-265

[54] Adams J., Sieve size statistics from grain measurement. Journal of Geology, Chicago, 1977, 85, 209-227

[55] Johnson M.R., Thin section grain size analysis revisited. Sedimentology, 1994, 41, 985-999

[56] Liu K.W., Greyling E.H., Grain size distribution and cementation of the Cretaceous Mzamba Formation of Eastern Cape, South Africa: A case study of a storm influenced offshore sequence. Sedimentary Geology, 1996, 107, 83-97

[57] Udden J.A., Mechanical composition of clastic sediments. Geol. Soc. Am. Bull., 1914, 25, 655-744

[58] Wentworth C.K., Method of computing mechanical composition types in sediments. Geol. Soc. Ameri. Bull., 1929, 40, 771-790

[59] Sahu B.K., Environments of deposition from the size analysis of clastic sediments: Ph.D. thesis, Univ. of Wisconsin, Madison, Wis., 1962

[60] Rajesh E., Anbarasu K., Rajamanickam G.V. Grain size distribution of silica sand in and around Marakkanam coast of Tamil Nadu. Jour. Geol. Soc. India, 2007, 69, 1361-1368

[61] Ramanathan A.L., Rajkumar K., Majumdar J., Singh G., Behera P.N., Santra S.C., Chidambaram S., Textural characteristics of the surface sediments of a tropical mangrove Sundarban ecosystem, India. Indian Journ. Mar Sci., 2009, 38(4), 397-403

[62] Hanamgond P.T., Chavadi V. C., Sedimentological study of Kwada and Belekeri bay beaches, Uttara Kannada, west coast, India. Jour. Geol. Soc. India, 1998, 51, 193-200

[63] Friedman G.M., Dynamic processes and statistical parameters compared for size frequency distribution of beach and river sands. Journal of Sedimentary Petrology, 1967, 37, 327-354

[64] Al-Ghadban A.N., Holocene sediments in a shallow bay, southern coast of Kuwait, Arabian Gulf. Mar. Geol., 1990, 92, 237-254

[65] Stewart H.B., Sedimentary reflection on depositional environment, in San Miguel lagoon, Baja California, Mexico, AAPG Bull., 1958, 42, 2567-2618

[66] Moiola R.J., Weiser D., Textural parameters: an evaluation. Journal of Sedimentary Petrology, 1968, 38, 45-53

[67] Griffith J.C., Scientific Methods in analysis of sediments. McGraw-Hill. New York USA., 1967

[68] Miall, A. D., Facies architecture in clastic sedimentary basins; in Kleinspehn, K., and Paola, C., eds., New Perspectives in basin 
analysis: Springer-Verlag, New York, 1988a, 63-81

[69] Miall, A. D., Architectural elements and bounding surfaces in channelized clastic deposits: notes on comparisons between fluvial and turbidite systems, in Taira, A., and Masuda, F., eds., Sedimentary facies in the active plate margin: Terra Scientific Publishing Company, Tokyo, Japan, 1988b, 3-15

[70] Ramanamurthy B.V., Gondwana sedimentation in Ramagundam-Mantheni area, Godavari Valley Basin. Jour. Geol. Soc. India, 1985, 26, 43-55

[71] Burhanuddin $M$. Textural analysis in interpreting the depositional environmental of Lower Gondwana Sandstone in central part of Godavari basin, Andhra Pradesh. Jour. Geol. Soc. India, 2007, 69, 1335-1341

[72] Murkute Y.A., Textural parameters and petrography of Kamthi Sandstone around Minijhari, Chandrapur district, Maharashtra. Jour. Indian Assoc. Sed., 2001, 20, 97-108
[73] Murkute Y.A. Lithofacies analysis, petrography and textural parameters of Kamthi Sandstone from Umrer coalfield, Nagpur district, Maharashtra. Gondwana Geol. Mag., 2002, 17, 19-32

[74] Kumar S., Singh I.B., Sedimentological study of Gomti river sediments, Uttar Pradesh, India. Senckenbergiana marit., 1978, 10 (4/6), 145-211

[75] Rajamanickam G.V., Muthukrishnan N., Grain size distribution in the Gadilam river Basin, Northern Tamil Nadu. Jour. Indian Assoc. Sed., 1995, 14, 55-66

[76] Sharda Y.P., Verma V.K., Paleo environment during Muree and Siwalik sedimentation around Udhampur, Jammy Himalaya. Publication of the centre of advanced study in Geology, No. II, Punjab University, Chandigarh, 1977 